\title{
Immobilization of superoxide dismutase/catalase onto polysulfone membranes to suppress hemodialysis-induced oxidative stress: A comparison of two immobilization methods
}

\author{
Filiz Yasar Mahlicli ${ }^{\mathrm{a}}$, Yasin Şen ${ }^{\mathrm{b}}$, Mehmet Mutlu ${ }^{\mathrm{c}}$, Sacide Alsoy Altinkaya ${ }^{\mathrm{a}, *}$ \\ a Department of Chemical Engineering, Izmir Institute of Technology, Gulbahce Kampusu, 35430 Urla, Izmir, Turkey \\ ${ }^{\mathrm{b}}$ Plasma Aided Bioengineering and Biotechnology (PABB) Research Group, Food Engineering Division, Institute for Pure and Applied Sciences, Hacettepe \\ University, Ankara, Turkey \\ ' Plasma Aided Biomedical (pabmed) Research Group, Biomedical Engineering Department, TOBB ETU University of Economics and Technology, \\ Ankara, Turkey
}

\section{A R T I C L E I N F O}

\section{Article history:}

Received 17 October 2014

Received in revised form

16 December 2014

Accepted 17 December 2014

Available online 3 January 2015

Keywords:

Superoxide dismutase

Catalase

Polysulfone membrane

Self assembly of polyelectrolyte (ionic

immobilization)

Plasma treatment

\begin{abstract}
A B S T R A C T
The objective of this study is to improve the blood compatibility of polysulfone (PSF) based hemodialysis membranes through generating antioxidative surfaces with superoxide dismutase (SOD)/catalase (CAT) enzyme couple immobilization. Enzymes were attached both covalently and ionically on the plasma treated and polyethyleneimine (PEI) deposited membranes, respectively. The loss of enzymes from PEI modified surface at the end of $4 \mathrm{~h}$ was found to be relatively higher during storage in phosphate buffered saline (PBS) at pH 7.4 when compared to the enzymes on the plasma treated surface. The kinetic studies indicated that SOD catalyzed the reaction in the diffusion-limited regime at all substrate concentrations and its inactivation by hydrogen peroxide was prevented in the presence of CAT. SOD/CAT coated PSF membranes were capable of reducing the levels of reactive oxygen species in blood and can significantly prolong activated partial thromboplastin time. In addition, both the adsorption of human plasma proteins and platelet activation on all modified membranes decreased significantly compared to the unmodified PSF membranes. Proposed modification methods did not affect high permeability, high mechanical strength or the non-toxic properties of the PSF membranes.
\end{abstract}

(c) 2015 Elsevier B.V. All rights reserved.

\section{Introduction}

Leukocyte adhesion and activation during blood-membrane interactions cause generation of free radicals. Reaction of these radicals with the proteins and lipids in blood is the main reason underlying hemodialysis-induced oxidative stress. To address this issue, several groups recently focused on developing hemodialysis membranes with antioxidative properties. The most commonly used approach is to immobilize antioxidants, such as vitamin E [1-3], linoleic acid [4-7], soybean-derived phytochemical, genistein [8] and alpha lipoic acid [9], on surfaces of the membranes that are in contact with blood. Antioxidant immobilization did not only allow for the inhibition of reactive oxygen species (ROS) generation but also reduced platelet adhesion and protein adsorption and prolonged blood coagulation time [4-7].

Superoxide dismutase (SOD) and catalase (CAT), two antioxidant enzymes in the body that always co-exist, constitute the

\footnotetext{
* Corresponding author. Tel.: +90 2327506658; fax: +90 2327506645.

E-mail address: sacidealsoy@iyte.edu.tr (S. Alsoy Altinkaya).
}

most effective system regulating the levels of free radicals. SOD degrades free radical superoxide anions to hydrogen peroxide and CAT removes hydrogen peroxide from the tissues, preventing the formation of other harmful free radicals. Encapsulation or immobilization of individual SOD or CAT was used in different applications, such as drug delivery [10] and biosensors [11]. However, there is a limited number of studies focused on SOD-CAT multienzyme immobilization [12].

In this study we aimed to utilize the unique antioxidant properties of SOD/CAT enzyme couple to suppress hemodialysis induced oxidative stress. For this purpose, the enyzmes were immobilized onto plasma modified and polyethyleneimine (PEI) deposited polysulfone membranes. Plasma-based approaches have gained considerable interest for immobilization of biomolecules, since they do not require complicated wet chemical steps to achieve binding allowing linker-free immobilization [13]. Moreover, in some conditions lowered stability of bioactive molecules due to usage of spacers can be prevented [14]. A key challenge for the plasma treatment process is aging as a result of post-plasma oxidation initiated by the reaction between remaining radicals and in-diffusing atmospheric oxygen as well as the movement of some of the polymer chains from the 
surface into the bulk [15]. Recently, adsorption of enzymes on polyelectrolyte-modified membrane surfaces has emerged as a versatile, gentle and easy method for immobilization [16-21] which occurs mainly via ionic binding of enzyme molecules to the charged surface. The adsorption process can be conducted in an aqueous solution under mild conditions which minimize the loss of enzyme activity. The main disadvantage of this method is the possible interference of ions in solution that are not involved in the ionic reaction leading to easy detachment of the enzyme. In this study, we evaluated the efficacies of these two immobilization techniques based on the blood compatibilities of the membranes. In particular, we measured the inhibition of ROS in blood plasma, the amount of adsorbed plasma proteins, the activated partial thromboplastin time (APTT), cytoxicity on blood cells and platelet adhesion and activation on the membranes. In addition, we also characterized the transport, structural and mechanical properties of the membranes. To the best of our knowledge, the SOD-CAT enzymes have not been used together previously to improve the hemocompatibility of hemodialysis membranes. Here we also demonstrated the first data on the change of the conformation and activity of this enzyme couple upon immobilization on polysulfone membranes.

\section{Materials and methods}

\subsection{Materials}

Polysulfone (PSF) with a molecular weight of $26,000 \mathrm{~g} \mathrm{~mol}^{-1}$, branched polyethylenimine (PEI) $\left(750,000 \mathrm{~g} \mathrm{~mol}^{-1}\right)$ which contains $25 \%$ of tertiary amine groups, $50 \%$ of secondary amine groups, and $25 \%$ primary amine groups, sodium alginate, 1-2-dichloroethane, chlorosulfonic acid and sodium dodecylsulfate (SDS) were puchased from Sigma-Aldrich. 1-methyl-2-pyrrolidone (NMP) with a purity of $\gg 98 \%$ and micro BCA protein assay reagent kit were purchased from Fluka and Thermoscientific, respectively. Bovine serum albumin $\left(65,000 \mathrm{~g} \mathrm{~mol}^{-1}\right)$, urea, vitamin $\mathrm{B}_{12}$, lysozyme, 2,2-diphenyl-1picrylhydrazyl, alpha-lipoic acid, superoxide dismutase and catalase enzymes and chemicals used for determining enzyme activities, nitro blue tetrazolium, L-methionine, EDTA, riboflavin and hydrogen peroxide, were also supplied by Sigma-Aldrich. Cell viability kits, thiazole orange (TO) and propidium iodide (PI), and the monoclonal antibodies, PAC1, FITC and CD62 PE, used for determining platelet activation were purchased from Becton Dickinson Immunocyometry Systems. $\mathrm{H}_{2} \mathrm{NaPO}_{4}$ and $\mathrm{Na}_{2} \mathrm{HPO}_{4}$ were from Fluka and Riedel, respectively. Water used in the experiments was distilled ionexchanged water.

Phosphate buffer solution was prepared with $0.05 \mathrm{M} \mathrm{H}_{2} \mathrm{NaPO}_{4}$ and $\mathrm{Na}_{2} \mathrm{HPO}_{4}$. It was buffered with saline for in vitro studies, which had a final concentration of $137 \mathrm{mM} \mathrm{NaCl}, 10 \mathrm{mM}$ phosphate, $2.7 \mathrm{mM} \mathrm{KCl}$, and a $\mathrm{pH}$ of 7.4.

Whole blood was taken from a healthy single donor with approval from the ethics committee.

\subsection{Preparation of the membranes}

Polysulfone and sulfonated polysulfone (PSF-SPSF) membranes were used as a support for enzyme immobilization and were prepared as described in our previous study [9]. Enzymes (SOD, CAT or SOD/CAT) were first immobilized via physical (ionic) bonding between the negatively charged enzyme and positively charged PEI located on the PSF-SPSF membrane. Initally, the PSF-SPSF support membrane was dipped in a $0.1 \mathrm{wt} \%$ PEI solution for $10 \mathrm{~min}$. In order to obtain a sufficiently protonated form of PEI, the pH of the PEI solution was adjusted by hydrochloric acid $(\mathrm{HCl})$ to a value of 8.0 which was under the isoelectric point of PEI ( $\mathrm{pH} 8.8$ ) [22-23]. After thorough washing to remove the excess polyelectrolytes, the membrane was immersed in a solution of $0.1-1.0 \mathrm{mg} \mathrm{ml}^{-1}$ of SOD and/or CAT ( $\mathrm{pH} \mathrm{7.4)}$ ) for $24 \mathrm{~h}$ at $4{ }^{\circ} \mathrm{C}$. The isoelectric point of SOD and CAT enzymes are 4.95 and 5.4, respectively, and they are highly negatively charged at the immobilization $\mathrm{pH}(\mathrm{pH} 7.4)$. In the second method, immobilization of enzymes was achieved with covalent bonding between amine groups on the surface of plasma treated PSF membranes and carboxylic groups of enzymes without using any intermediate chemical linker groups. Amine groups on the surface of the PSF membranes were created by means of plasma polymerization (PlzP) of ethylenediamine (EDA) under various conditions including low frequency (LF) and radio frequency (RF) plasma system (PICO-type plasma equipment), discharge power (30-150 W) and exposure time (10-30 min). The plasma chambers were stainless steel (150 mm radius and $320 \mathrm{~mm}$ length). A $40 \mathrm{kHz}$ LF generator (power range 0-200 W) and a $13.6 \mathrm{MHz}$ RF generators (power range $0-100 \mathrm{~W}$ ) were used to sustain the plasma in the reactors. Plasma polymerization was carried out in the fully closed and semi-automatic system. The plasma procedure was carried out in the same way for both LF and RF plasma systems. The membranes were placed onto the ground electrode in the middle of the reactor. To generate plasma, firstly low pressure was created in a recipient by means of a vacuum pump (Trivac, Germany). At a pressure of approximately $0.1 \mathrm{mbar}$, monomer EDA vapor was fed into the chamber and allowed to flow at a special rate from $0.1 \mathrm{mbar}$ to 0.3 mbar. Next, the plasma power was adjusted and the membranes were exposed to glow-discharge. At the end of the process, the plasma generator was turned off automatically and monomer inlet was closed manually. The plasma system was fed with argon gas for $10 \mathrm{~min}$. and then placed in $0.1 \mathrm{mbar}$ vacuum pressure for $15 \mathrm{~min}$. Argon feeding and vacuum applications were applied to deactivate free radicals in the plasma atmosphere. The details of the plasma modification of surfaces carried out by our research group were given elsewhere [24-29]. For the immobilization of enzymes, the plasma treated membranes were immersed directly in a solution of $0.1-1.0 \mathrm{mg} \mathrm{ml}^{-1}$ of SOD or CAT ( $\mathrm{pH} \mathrm{7.4)} \mathrm{for} 24 \mathrm{~h}$ at room temperature. The amount of immobilized enzymes was determined using the Bradford method, which utilizes the principle of protein-dye binding [30].

\subsection{Surface characterization studies}

Contact angle measurements for distilled water were carried out with a Attension Optical tensiometer by means of a horizontal microscope, equipped with a video camera which is connected to a computer. The volume of a liquid drop varied between 3 and $5 \mu \mathrm{l}$. The contact angle was calculated from the droplet screen image. Each reported contact angle measurement represents an average value of five separate drops on different areas of the membranes obtained from three different batches. Contact angle measurements for n-octane and air were carried out to determine the total surface free energy of membranes $\left(\gamma_{s v}\right)$ and the interfacial free energy between water and membrane surfaces $\left(\gamma_{s w}\right)$ which are composed of the polar component $\left(\gamma_{s v}^{p}\right)$ and the dispersive component $\left(\gamma_{s v}^{d}\right)$ of the total surface free energy (Eqs. (1) and (2)).

$\gamma_{s v}=\gamma_{s v}^{p}+\gamma_{s v}^{d}$

$\gamma_{s w}=72.8+\gamma_{s v}-9.3 \sqrt{\gamma_{s v}^{d}}-14.3 \sqrt{\gamma_{s v}^{p}}$

We identified the change in surface charge of the membrane caused by polyelectrolyte deposition through staining of the membranes. The negatively charged groups (carboxyl and sulfonate groups) on the membrane can form complexes with toluidine blue $\mathrm{O}$ dye at $\mathrm{pH} 10$ and the positively charged groups (amine groups) with congo red at $\mathrm{pH}$ 7. The staining was performed by 
dipping the membranes in a $30 \mathrm{ppm}$ solution of the dye dissolved in its associated solvent for $30 \mathrm{~min}$, followed by washing the sample until the solvent became colorless [31]. The amount of the charged groups on the membranes stained with toluidine blue $\mathrm{O}$ and congo red was determined spectrophotometrically in the visible region (Aventes-Avemouse62). The intensity of each color resulting from adsorption of dyes on the membranes was reported as an average of 10 measurements.

The deposition and conformation of enzymes were followed by Attenuated Total Reflectance Fourier Transform Infrared Spectroscopy (ATR-FTIR) (80 scans, $4 \mathrm{~cm}^{-1}$ resolution, wavelength range 4000-650 $\left.\mathrm{cm}^{-1}\right)$ measurements.

To determine the surface roughness of the membranes, a topographical map of the membrane surfaces was obtained with Atomic Force Microscopy (AFM) on a Digital Instruments MMSPM Nanoscope IVmodel. $10 \mu \mathrm{m} \times 10 \mu \mathrm{m}$ surface was scanned with $512 \times 512$ pixel resolution using a silicon tip attached to a cantilever, while maintaining a constant force between the tip and the sample.

The bulk morphology of the membranes was examined by scanning electron microscopy (SEM) on a FEI-Quanta 250 FEG model. The samples were coated with gold using a Magnetron Sputter Coating Instrument.

\subsection{Measurement of superoxide dismutase (SOD) activity}

The antioxidant activities of free and immobilized SOD were determined by measuring the ability to inhibit the photochemical reduction of Nitrotetrazolium Blue Chloride (NBT). The experiments were conducted in $3 \mathrm{ml}$ disposable cuvettes at $35^{\circ} \mathrm{C}$. Each $3 \mathrm{ml}$ mixture contained $2 \mathrm{ml}$ Sodium phosphate buffer (PBS) of $50 \mathrm{mM}$ at pH 7.4, $200 \mu \mathrm{l} 75 \mu \mathrm{M}$ NBT, 13 mM Methionine, 100 nM EDTA and $30 \mu \mathrm{l}$ of $0.025 \mathrm{mg} \mathrm{ml}^{-1}$ of SOD. Lastly, $200 \mu \mathrm{l}$ of $2 \mu \mathrm{M}$ riboflavin solution was added, the cuvettes were shaken and the reaction was started under illumination of a $15 \mathrm{~W}$ fluorescent lamp. Each sample was kept under the light for 10 min before the lamp was switched off in order to stop the reaction. Two absorbance data points were collected for each sample: before adding the riboflavin solution into the cuvette and after the $10 \mathrm{~min}$ time period was completed. The absorbance of each sample was measured by a UV-spectrophotometer (Perkin Elmer, model no: Lambda 45) at $560 \mathrm{~nm}$ against a $3 \mathrm{ml}$ solution of PBS. Each measurement was repeated five times for each test. To determine immobilized SOD activity, instead of using free enzyme, $1 \mathrm{~cm}^{2}$ membrane was immersed into $3 \mathrm{ml}$ reaction mixture.

SOD activity is expressed as the percentage of inhibition in reduction of NBT (inhibition of the formazan production) per $g$ of SOD (or $\mathrm{cm}^{2}$ membrane). The amount of superoxide dismutase required to inhibit the rate of formation of formazan by $50 \%$ is defined as $1 \mathrm{U}$ of activity.

\subsection{Measurement of catalase (CAT) activity}

The antioxidant activities of free and immobilized CAT were determined by measuring the amount of hydrogen peroxide consumed enzymatically where hydrogen peroxide $\left(\mathrm{H}_{2} \mathrm{O}_{2}\right)$ was used as a substrate. In order to determine the free activity of CAT, $25 \mu \mathrm{l}$ of $0.01 \mathrm{mg} \mathrm{ml}^{-1} \mathrm{CAT}$ was added into $2 \mathrm{ml} \mathrm{H}_{2} \mathrm{O}_{2}$ solution. This reaction mixture was allowed to incubate for $10 \mathrm{~min}$ at $25{ }^{\circ} \mathrm{C}$ inside a lightfree container. The absorbance of each cuvette was measured before and after the reaction by a UV-spectrophotometer (Perkin Elmer, mode no: Lambda 45) at $240 \mathrm{~nm}$ against a $2.0 \mathrm{ml}$ PBS. The immobilized CAT activity of the membranes was determined by immersing a $1 \mathrm{~cm}^{2}$ membrane into a $2 \mathrm{ml}$ volume of $\mathrm{H}_{2} \mathrm{O}_{2}$.

The activity of free catalase was given as $\mathrm{U} / \mathrm{mg}$ protein and immobilized catalase activities were expressed as $\mathrm{U} \mathrm{mg}^{-1}$ protein or $\mathrm{U} \mathrm{cm}^{-2}$ membrane where $1 \mathrm{U}$ is defined as $\mu \mathrm{mol} \mathrm{H}_{2} \mathrm{O}_{2} \mathrm{~min}^{-1}$.

\subsection{Determination of operational stability of the immobilized enzymes}

To determine the stability of immobilized SOD or CAT, membranes were immersed into $25 \mathrm{ml}$ of $0.05 \mathrm{M}$ phosphate buffer solution at $\mathrm{pH} 7.4$ and $37{ }^{\circ} \mathrm{C}$ for $4 \mathrm{~h}$ which corresponds to a typical hemodialysis period. The solution was stirred thoroughly and the membrane samples were removed from the solution at the end of 240 min. The enzymatic activities were measured using same procedure described above.

\subsection{Hemocompatibility experiments}

Hemocompatibility of the membranes prepared was evaluated in terms of blood protein adsorption, platelet activation, blood coagulation time, ROS levels in plasma and cell viability. The protocols for each hemocompatibility measurement were described in detail in the study of Mahlicli and Altinkaya [9].

\subsection{Permeation experiments}

Permeation experiments were carried out in a side by side diffusion cell (Permegear Membrane Transport Systems) using urea, vitamin $B_{12}$ and lysozyme as model solutes. The overall mass transfer coefficient which has contributions both from the bulk fluid and the membrane was evaluated from the solute concentration data. The effective permeability of the solute was then determined from the overall and individual mass transfer coefficients [32].

\subsection{Mechanical tests}

The tensile strength of the membranes was measured using a Shimadzu AG-I-250 KN testing machine. The membranes were strained at constant rates of $0.25 \mathrm{~mm} \mathrm{~min}^{-1}$ and $0.5 \mathrm{~mm} \mathrm{~min}-1$ until failure. The test method and sample preparation is in accordance with ASTM D 882-02 standard. At least five test coupons $10 \mathrm{~mm}$ in width and $5 \mathrm{~cm}$ in length were used for measurements.

\subsection{Data analysis}

Statistical evaluation of the data was performed using Student's paired $t$ test. The probability $(p)$ values $p<0.05$ were considered to be statistically significant differences. The results were expressed as mean \pm standard error and the propagation of error was taken into account.

\section{Results and discussion}

In this study, superoxide dismutase (SOD)-catalase (CAT) enzyme mixture was immobilized onto the polysulfone membranes by modifying and activating the surface with PEI deposition or plasma treatment. To compare kinetic parameters, both enzymes were also immobilized individually thus a total of 6 membranes were prepared (Table 1). In the following section, free and immobilized enzyme kinetics and the biocompatibility, transport and mechanical properties of the modified membranes are discussed.

\subsection{Optimization of the plasma treatment parameters}

To obtain the optimum plasma treatment parameters, plasmagenerating conditions (plasma treatment time and power) were varied and the interfacial free energy $\left(\gamma_{s w}\right)$ calculated using the contact angle measurements are given in Fig. 1. Data for RF studies 
Table 1

Codes of the unmodified and modified PSF membranes.

\begin{tabular}{|c|c|c|c|c|c|}
\hline \multirow[t]{2}{*}{ Membrane code } & \multicolumn{3}{|c|}{ Weight percentages (wt\%) } & \multirow[t]{2}{*}{ Molecule type on the last layer } & \multirow[t]{2}{*}{ Immobilization method } \\
\hline & PSF & SPSF & NMP & & \\
\hline PSF-PLS & 20 & 0 & 80 & - & - \\
\hline PSF-PLS-CAT & 20 & 0 & 80 & CAT & Covalent bonding through plasma treated surface \\
\hline PSF-PLS-SOD & 20 & 0 & 80 & SOD & \\
\hline PSF-PLS-SOD/CAT & 20 & 0 & 80 & SOD/CAT & \\
\hline PSF-SPSF-PEI-CAT & 10 & 10 & 80 & CAT & Ionic bonding through PEI coated surface \\
\hline PSF-SPSF-PEI-SOD & 10 & 10 & 80 & SOD & \\
\hline PSF-SPSF-PEI-SOD/CAT & 10 & 10 & 80 & SOD/CAT & \\
\hline
\end{tabular}

were not included since the results obtained in LF studies were more stable and accurate than RF studies. Plasma treatment applied to membrane surfaces led to significant decreases in $\gamma_{s w}$ values where the low values of $\gamma_{s w}$ correspond to a high interaction between the surface and water. It was found that $\gamma_{s w}$ value for unmodified PSF membrane decreased from $8.274 \mathrm{~mJ} / \mathrm{m}^{2}$ to $0.669 \mathrm{~mJ} / \mathrm{m}^{2}$ (90 W; $20 \mathrm{~min}$ ) and $0.979 \mathrm{~mJ} / \mathrm{m}^{2}$ (60 W; $30 \mathrm{~min}$ ) after surface modification. Although the parameters of $90 \mathrm{~W}$ plasma power and 20 min plasma treatment time make the surface more hydrophilic, in our experiments we used $60 \mathrm{~W}$ and $30 \mathrm{~min}$, since this combination provided a more stable membrane surface.

\subsection{Optimization conditions for SOD/CAT immobilization}

It is well-known that the activity of enzymes is influenced by the $\mathrm{pH}$, temperature, concentration of the enzyme solution and immobilization time. Previously, the optimum immobilization time and temperature for catalase were reported as $24 \mathrm{~h}$ and $5{ }^{\circ} \mathrm{C}$ [33-34]. Based on these results, in this study, the SOD and CAT enzyme immobilizations were carried out at $4{ }^{\circ} \mathrm{C}$ and physiological pH of 7.4 within $24 \mathrm{~h}$ by varying the initial enzyme and PEI concentrations. Enzymes did not show significantly different activities when adsorbed on two different support membranes that were modified with $0.1 \mathrm{mg} \mathrm{ml}^{-1}$ or $1 \mathrm{mg} \mathrm{ml}^{-1}$ of PEI solution (Fig. 2). We concluded that $0.1 \mathrm{mg} \mathrm{ml}^{-1}$ of PEI, was sufficient to cover the negatively charged surface of the support membrane. The influence of enzyme concentration on the immobilized amount and the activity is shown in terms of specific activities ( $U$ mg enzyme ${ }^{-1}$ ) in Fig. 3. The highest specific activity was obtained with the lowest initial concentrations of SOD and CAT. At high enzyme concentrations, the activity decreased since the membrane surface is over-saturated and protein-protein interactions between the loaded enzyme molecules become more dominant both of which hinder substrate diffusion and conversion. Fig. 4 shows the change in catalytic activities of the membranes during a $4 \mathrm{~h}$ period. The highest loss in the activity $(45 \pm 8.2 \%)$ was observed for the membrane immersed into $0.1 \mathrm{mg} \mathrm{ml}^{-1}$ enzyme concentration during immobilization. The other membranes prepared with $0.25 \mathrm{mg} \mathrm{ml}^{-1}(20 \% \pm 3.9)$ and $0.5 \mathrm{mg} \mathrm{ml}^{-1}(16 \pm 3.1 \%)$ enzyme concentrations showed similar loss in their catalytic activities at the end of $4 \mathrm{~h}$. On the basis of these results, the optimum enzyme concentration for immobilization was chosen as $0.25 \mathrm{mg} \mathrm{ml}^{-1}$.

\subsection{Characterization of membranes}

The prepared membranes were characterized to determine their hydrophilic character, roughness, bulk structure and the change in the conformation of the enzymes upon immobilization.

The water contact angle values in Fig. 5 illustrated the enhanced hydrophilic character of the PSF surface after plasma treatment. The hydrophilicities of PSF-SPSF blend membrane or PEI modified and plasma activated PSF membranes were found to be similar $(p>0.05)$.

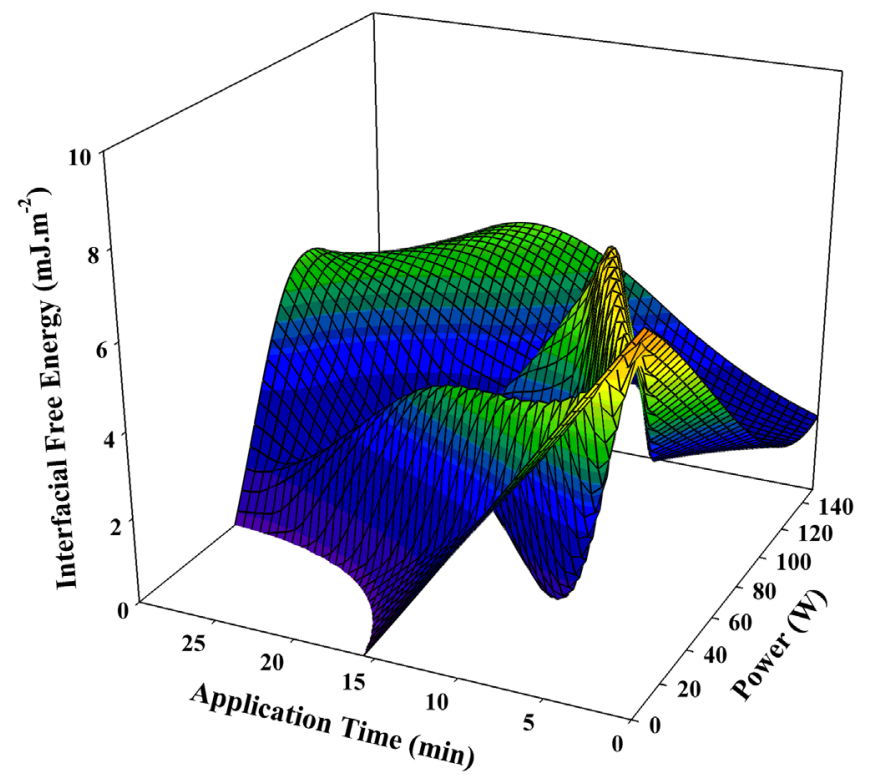

Fig. 1. Interfacial free energies of unmodified and LF plasma modified PSF membranes.

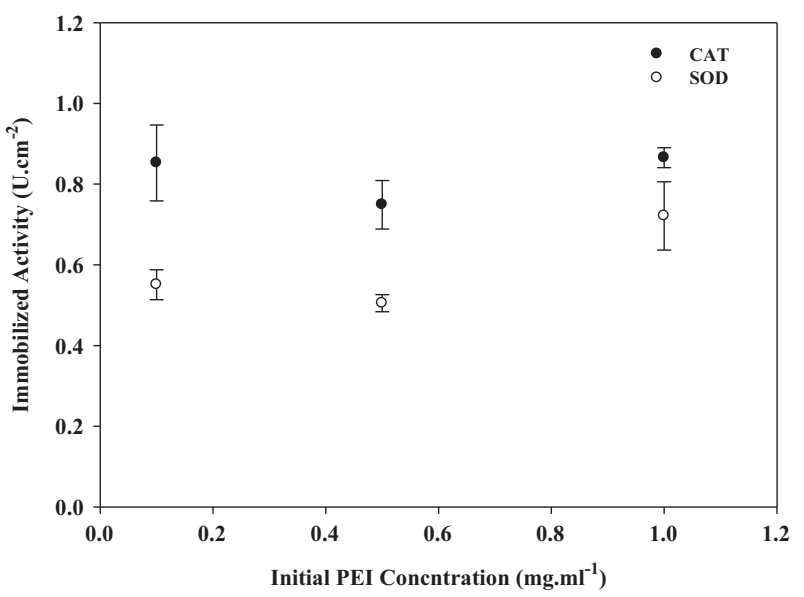

Fig. 2. Amount of SOD and the activity of SOD immobilized on the (a) PEI modified and (b) plasma treated surfaces. Experimental conditions applied during membrane preparation and activity measurements are: $C_{\mathrm{PEI}-\text { initial }}: 0.1 \mathrm{mg} \mathrm{ml}^{-1}$ and $C_{\text {Riboflavin }}: 2 \mu \mathrm{M}$.

Immobilization of SOD/CAT enzymes either covalently on plasma treated or ionically on PEI adsorbed surfaces significantly decreased the hydrophobicity of the starting PSF membrane.

The surface roughness of the membranes obtained from the AFM images (Fig. 6) is shown in Fig. 7. The unmodified PSF membrane had the smoothest surface which did not change significantly after plasma treatment or enzyme immobilization on the plasma treated 
a

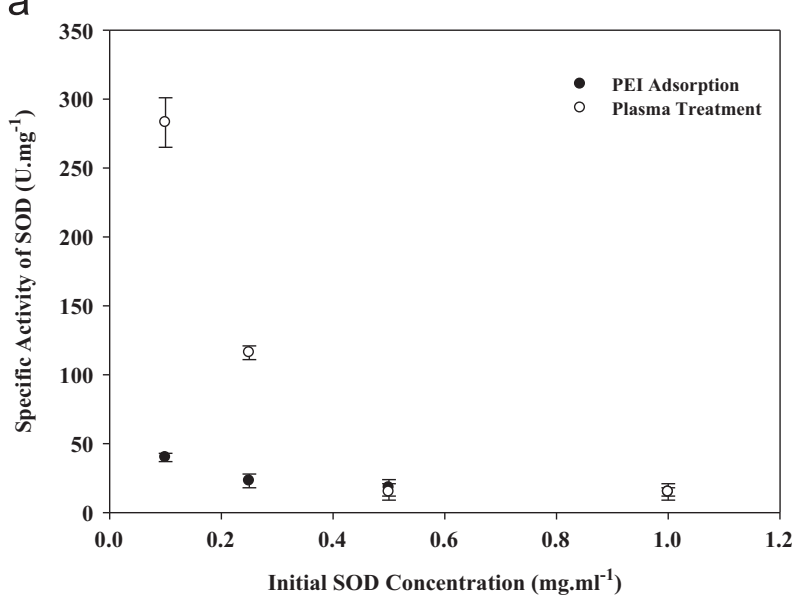

b

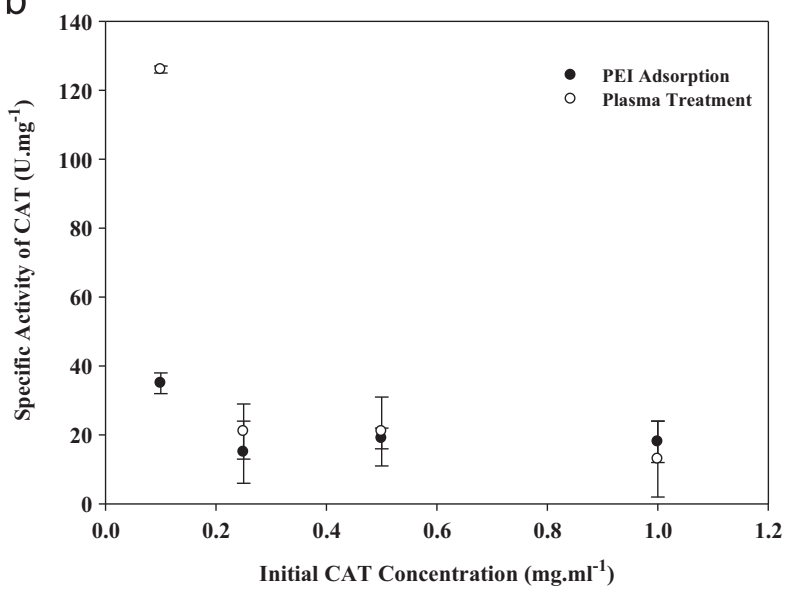

Fig. 3. Specific activities of immobilized (a) SOD and (b) CAT enzymes.

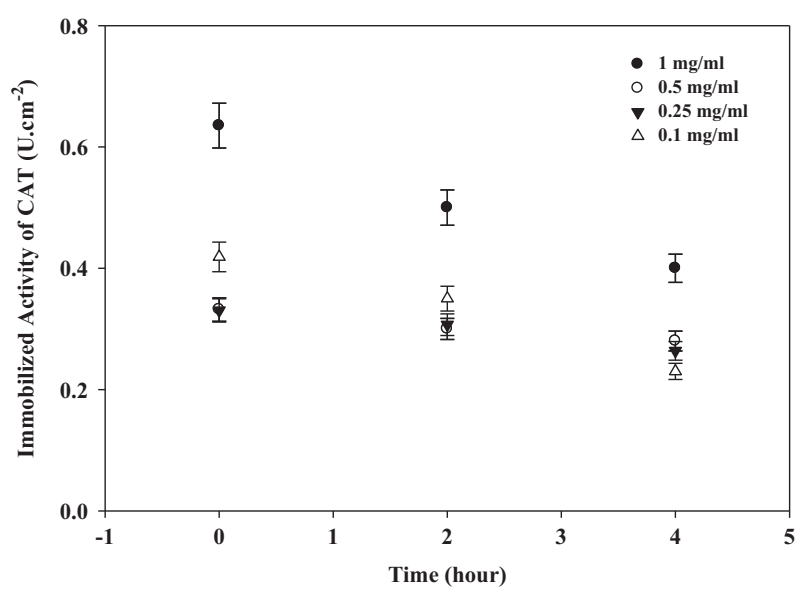

Fig. 4. Stability of CAT immobilized on PSF-SPSF-PEI membrane.

surface. Blending PSF with sulfonated PSF (PSF-SPSF) adversely affected the smoothness of PSF membrane while PEI deposition (PSF-SPSF-PEI) significantly decreased the surface roughness. This can be attributed to the conformational change of PEI to minimize the surface area as a result of diffusional mobility of its chains. When compared to the roughness of the PSF-SPSF-PEI-SOD/CAT membrane, the roughness upon immobilization on the plasma treated surface (PSF-PLS-SOD/CAT) was found to be smaller. This is due to

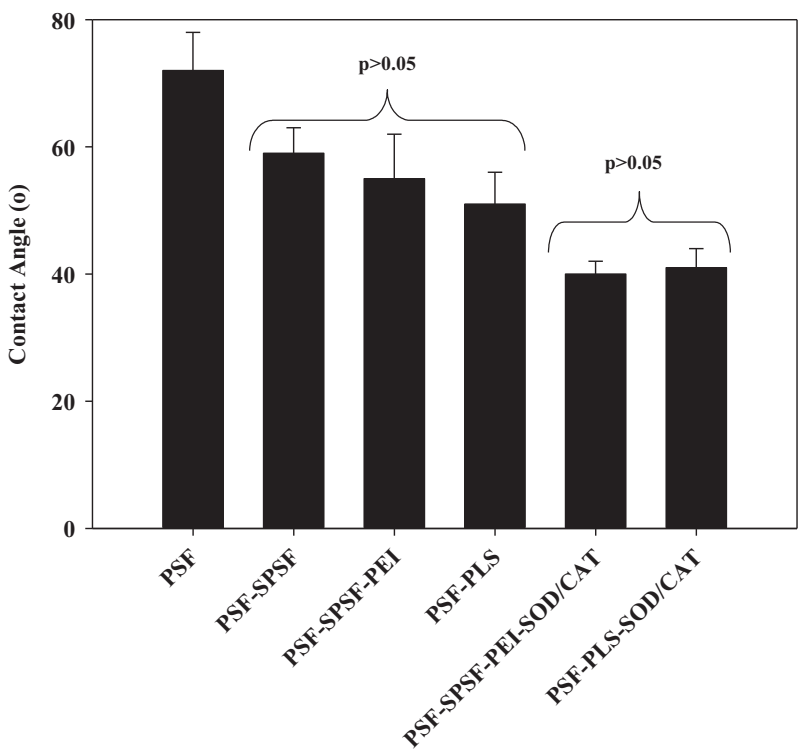

Fig. 5. Water contact angles of unmodified and modified PSF membranes.

the restricted motion of the enzyme molecules on the plasma treated surface as a result of the strong and rigid covalent bonding.

Changes in the bulk structure of the PSF membrane through blending with SPSF, plasma treatment and enzyme immobilization were observed with SEM. Fig. 8 shows that native (PSF) and modified membranes all have asymmetric structures where blending with SPSF increased the porosity of the PSF membrane. On the other hand, the pore size of the blend (PSF-SPSF) membrane decreased with PEI penetration, hence, the bulk structures of the PSF-SPSF-PEI-SOD/CAT and PSF membranes were found to be of similar morphology. The SEM pictures also illustrated that neither plasma treatment nor enzyme immobilization on the plasma treated surface changed the bulk structure of the unmodified PSF membrane.

Fig. 9a illustrates the ATR-FTIR spectrum of native SOD/CAT enzyme couple. In the spectrum, the amide I, amide II and amide III bands are located at approximately $1650 \mathrm{~cm}^{-1}, 1550 \mathrm{~cm}^{-1}$ and $1290 \mathrm{~cm}^{-1}$. The amide I band is a strong and broad band containing several spectral contributions arising from different types of protein secondary structures. Additional vibrational bands, which are not assigned to structured features but originate from the various side chains, were also observed. The strongest ones are 1082, 1455 and $1467 \mathrm{~cm}^{-1}$. The bands centered at $1467 \mathrm{~cm}^{-1}$ and $1455 \mathrm{~cm}^{-1}$ belong to protein side chain deformation vibrations $\left(\mathrm{CH}_{3}\right.$ and $\mathrm{CH}_{2}$, respectively), while the strong band at $1082 \mathrm{~cm}^{-1}$ can be attributed to $\mathrm{C}-\mathrm{C}$ and $\mathrm{C}-\mathrm{O}$ vibrations [35]. The broad $\mathrm{NH}_{2}$ band centered on $3200 \mathrm{~cm}^{-1}$ is usually overlapped with the $\mathrm{OH}$-stretching band of hydrating $\mathrm{H}_{2} \mathrm{O}$ molecules. The ATR-FTIR spectrum of SOD/CAT couple immobilized on PEI modified and plasma activated surfaces are shown in Fig. 9b and c, respectively. This method gives an insight into the structure down to few hundred nanometers below the outer surface, which is much deeper than the thickness of the immobilized enzyme layer. The presence of the most characteristic amide I and amide II bands in the range of $1700-1500 \mathrm{~cm}^{-1}$ confirms successful immobilization of the enzymes. The higher peak intensity of amide bonds for PSF-PLS-SOD/ CAT membrane also clearly reveals the presence of the amide bond formed by enzyme immobilization.

ATR-FTIR analysis was also used to investigate how the surface properties of the membranes affected the conformation of immobilized enzymes and the resulting enzymatic activity. Little conformational information can be obtained directly from the original IR spectra of the enzymes (Fig. 9a-c). Since the assignment of 
a

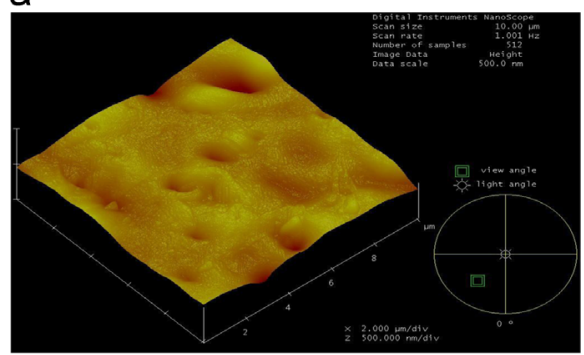

b

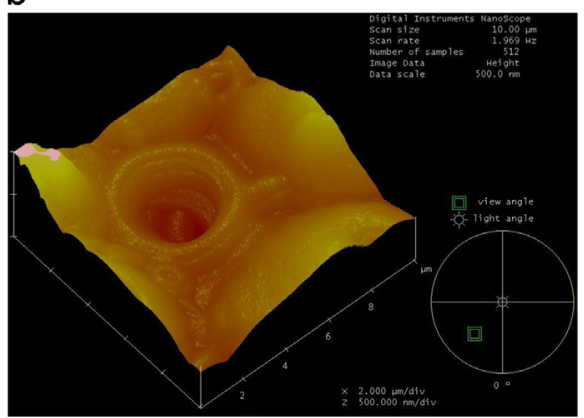

C

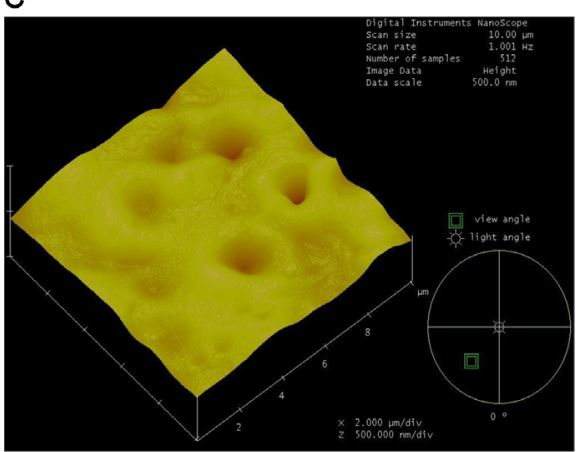

d

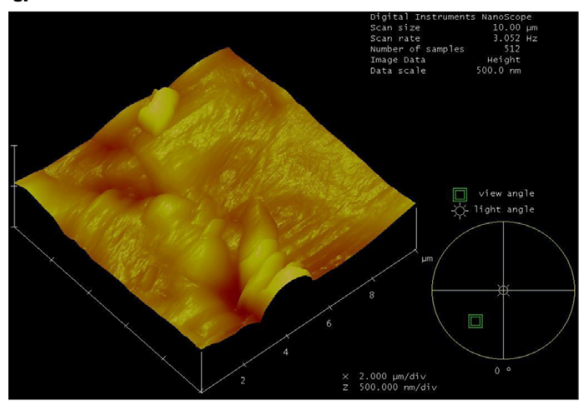

e

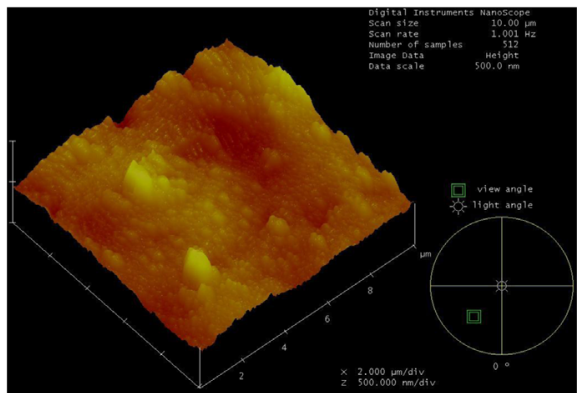

Fig. 6. AFM images of (a) PSF (b) PSF-SPSF (c) PSF-PLS (d) PSF-PLS-SOD/CAT and (e) PSF-SPSF-PEI-SOD/CAT membranes.

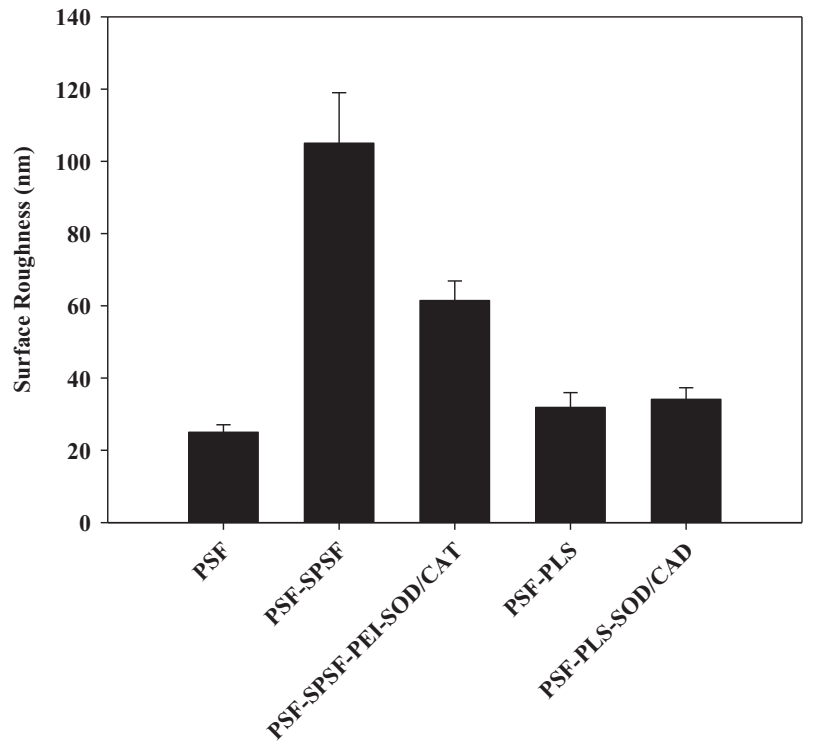

Fig. 7. Surface roughness of unmodified and modified PSF membranes.

amide I absorbance components provides more detailed information about the secondary structures, in turn the conformation integrity of enzymes, the FTIR spectra in the $1600-1700 \mathrm{~cm}^{-1}$ region was deconvoluted (Fig. 9d-f). The contents of each band in the total amide I absorbance obtained by integrating each component are summarized in Table 2. It is known that the secondary structure of $\mathrm{Cu}-\mathrm{Zn}$-SOD (determined by $\mathrm{x}$-ray crystallographic structural analysis) contains more than $50 \%$ of $\beta$ strands and turns and approximately $40 \%$ of unordered structures with a small fraction of $\alpha$-helix [36]. The major feature of Cu-Zn-SOD secondary structures is that the enzyme contains 8-stranded beta-barrel with the active site held between the barrel and two surface loops [37]. $\beta$-strand structure is an important determinant in stability of the $\mathrm{Cu}-\mathrm{Zn}-\mathrm{SOD}$. The secondary structure of CAT consists of $30 \% \alpha$ helical, 34\% $\beta$-sheet, $17 \% \beta$-turn and $19 \%$ unordered structures [38]. In this case, $\alpha$-helix is the preferred determinant of the CAT structural integrity [39]. In the context of protein structure, the term stability is usually defined as the tendency to maintain a native conformation [40]. Hence, the change in the content of $\beta$ strand and $\alpha$-helix of immobilized SOD-CAT with respect to native SOD-CAT was used to determine the stability of immobilized enzymes and the results are shown in Table 2.

SOD immobilized onto plasma treated or PEI modified surfaces had similar $\beta$-sheet content with the native enzyme, indicating no significant conformational change upon immobilization. On the other hand, the CAT enzyme lost its native conformation when adsorbed onto both surfaces as confirmed by a decrease in $\alpha$-helix content from $30 \%$ to $16 \%$ and $13 \%$, respectively. CAT $\left(250,000 \mathrm{~g} \mathrm{~mol}^{-1}\right)$ is a larger molecule compared to SOD $\left(32,500 \mathrm{~g} \mathrm{~mol}^{-1}\right)$ and is preferentially adsorbed on the membrane surface. In addition, adsorption of SOD on the CAT, and hence, consequent interactions between CAT and SOD molecules may have influenced the conformation of CAT.

$\mathrm{H}_{2} \mathrm{O}_{2}$, the product of the reaction catalyzed by SOD and the substrate of the reaction catalyzed by CAT, is a known denaturant. To observe conformational change in the presence of $\mathrm{H}_{2} \mathrm{O}_{2}$, ATR-FTIR analyses were repeated after the immobilized enzymes were incubated for $10 \mathrm{~min}$ (reaction time) in a $30 \mathrm{mM} \mathrm{H}_{2} \mathrm{O}_{2}$ solution. The results indicated that the $\beta$-sheet content of SOD decreased from $39 \%$ 
a

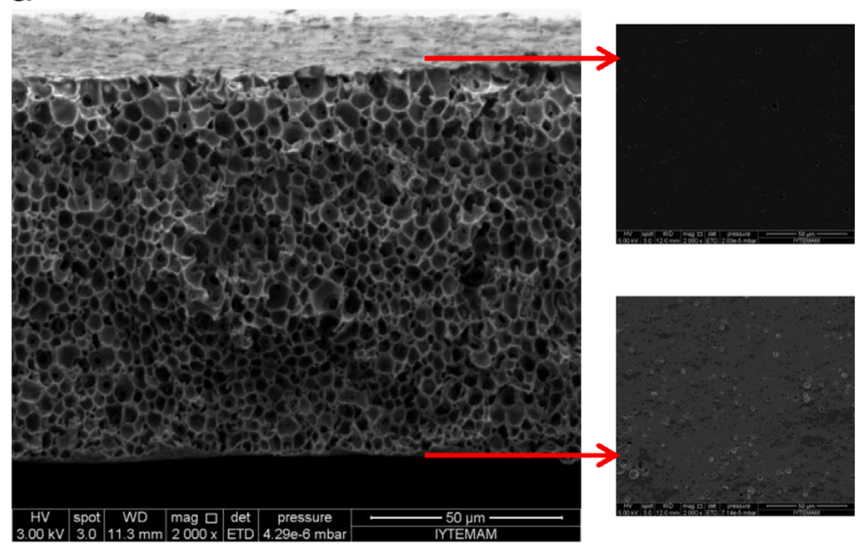

$\mathrm{b}$

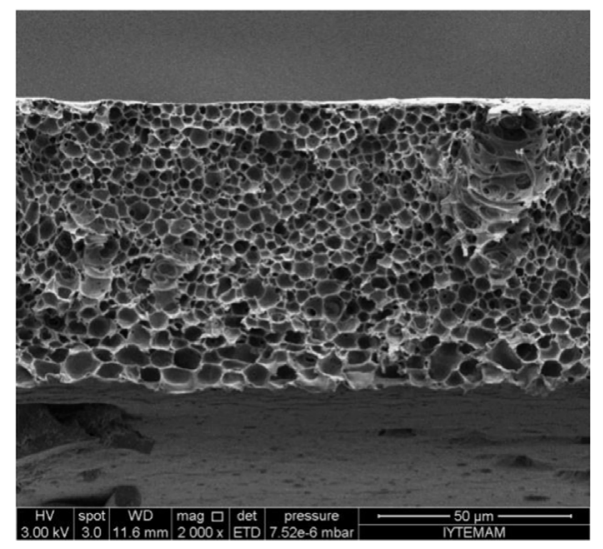

C

d

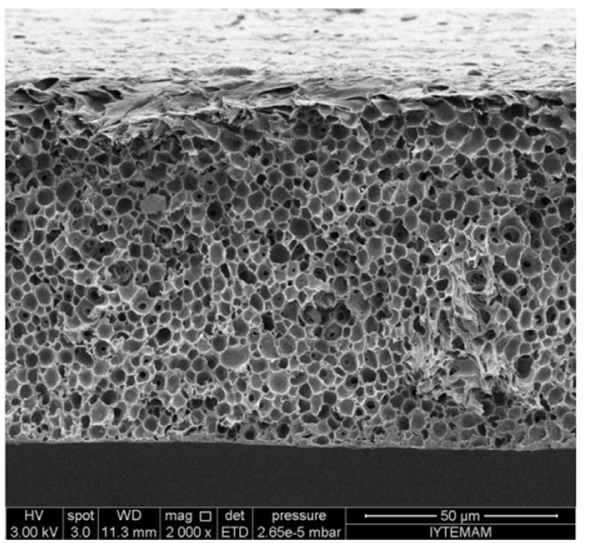

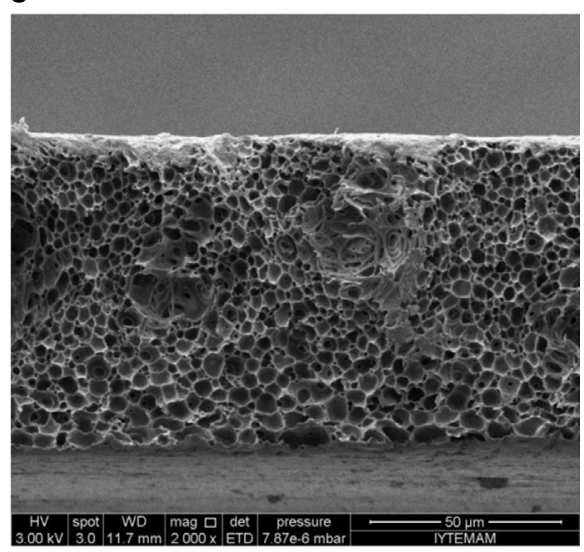

e

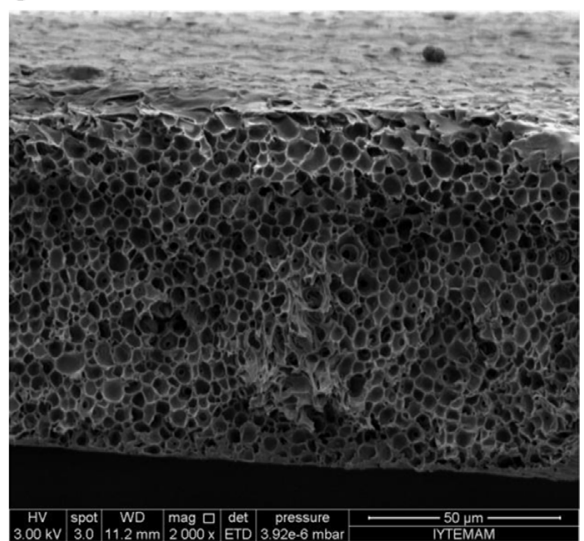

Fig. 8. SEM pictures of (a) PSF (b) PSF-SPSF (c) PSF-SPSF-PEI-SOD/CAT (d) PSF-PLS (e) PSF-PLS-SOD/CAT membranes. Magnification 2000 $\times$.

to $23 \%$ and from $37 \%$ to $13 \%$ when SOD was immobilized onto plasma treated and PEI modified surfaces, respectively. The conformation of an adsorbed enzyme is strongly influenced by the surface characteristics of the membranes, hence, the interaction forces (electrostatic interactions, hydrogen bonding, hydrophobic and van der Waals interactions) between the membrane surfaces and the enzymes. Since the hydrophilicities of the PEI modified and plasma treated surfaces are similar, the difference in the stabilities of the enzymes immobilized onto two different modified surfaces is likely due to the difference in the surface roughness and surface charge of the membranes. $\alpha$-helix content of the CAT enzyme did not change after immobilization and incubation in $\mathrm{H}_{2} \mathrm{O}_{2}$ suggesting that $\mathrm{H}_{2} \mathrm{O}_{2}$ dosage of $30 \mathrm{mM}$ is not denaturant against CAT enzyme.

\subsection{Stability of immobilized SOD/CAT}

Fig. 10 shows the change in the enzyme activities when the membranes were stored at $37^{\circ} \mathrm{C}$ in $\mathrm{pH} 7.4$ phosphate buffer solution for $4 \mathrm{~h}$. The losses in the initial CAT activities were $21 \%$ and $32 \%$, while corresponding values for the SOD were $23 \%$ and $37 \%$ when the enzyme couple was co-immobilized on the plasma treated and PEI modified surfaces, respectively. After storing in PBS buffer for $4 \mathrm{~h}$, the amount of SOD and CAT enzymes remaining on the plasma treated surface was found to be higher than that on the PEI modified surface (Fig. 11) due to stronger attachment between the enzymes and plasma treated surface via covalent bonding. On the other hand, one might argue that 20\% detachment from 
a

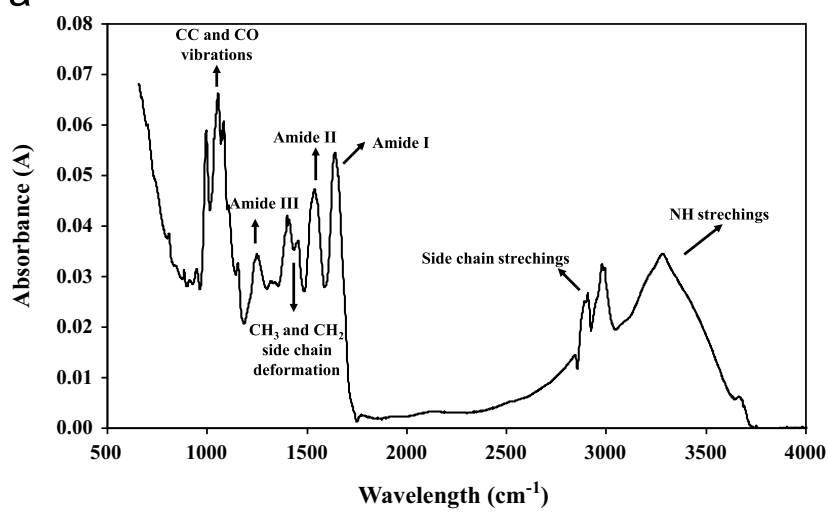

b

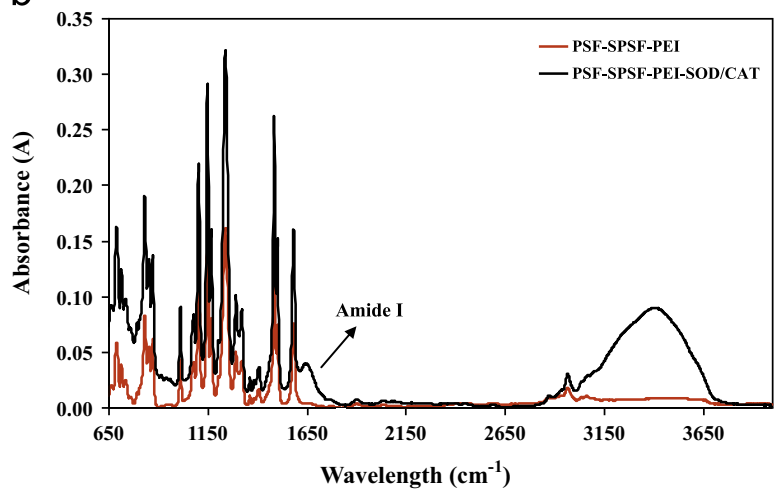

C

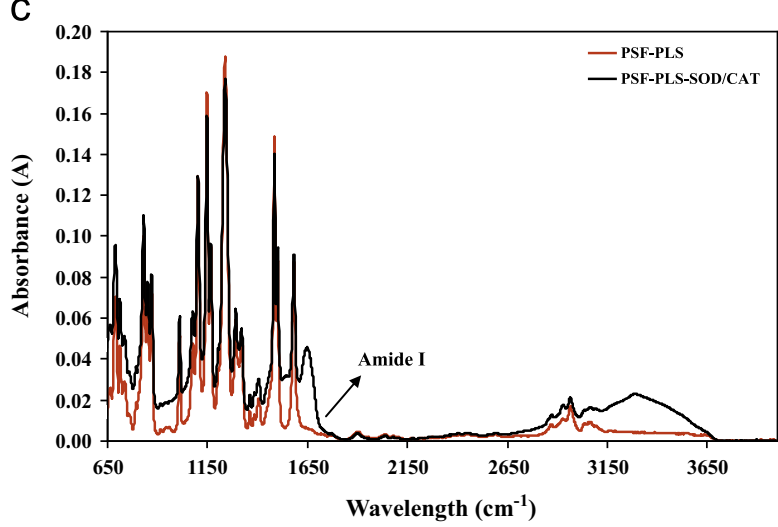

d

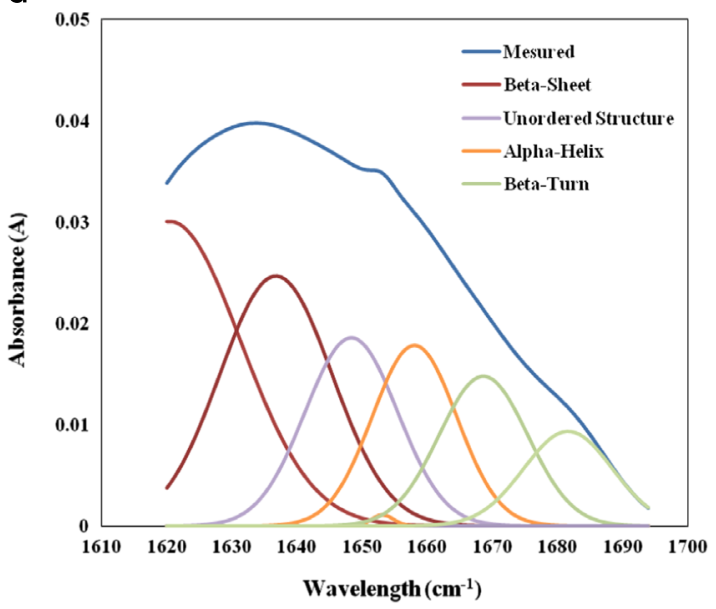

e

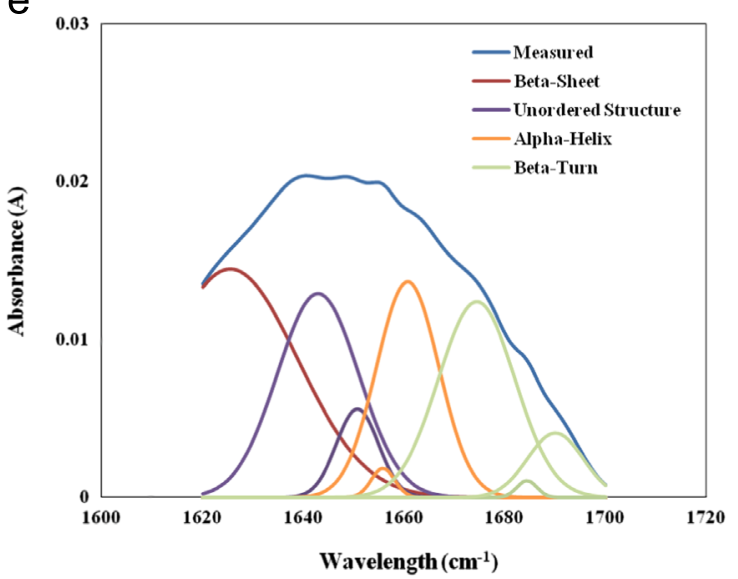

f

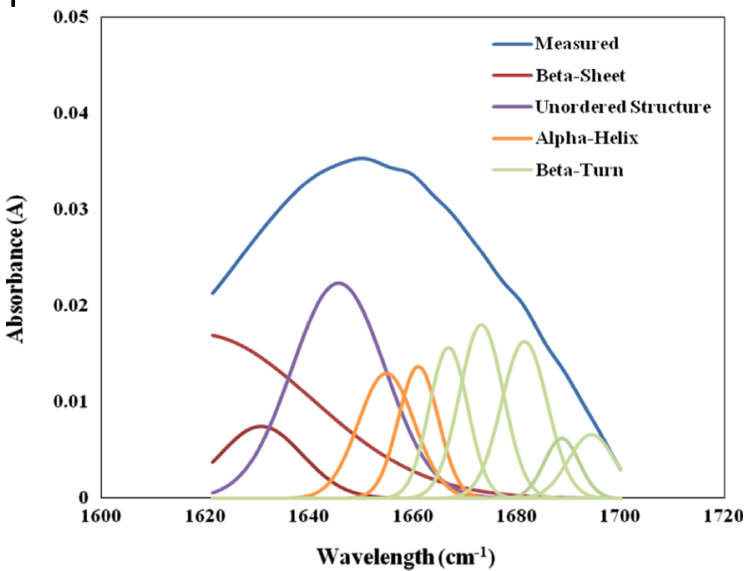

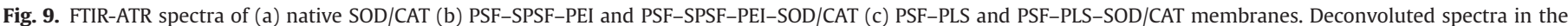
chosen band (1600-1700 $\mathrm{cm}^{-1}$ ) of (d) native SOD/CAT (e) PSF-SPSF-PEI-SOD/CAT (f) PSF-PLS-SOD/CAT membranes.

plasma treated surface is still high. This simply indicated that 10 min of washing was not enough to eliminate loosely-bound enzymes through nonspecific binding. However, this relatively short time period was chosen to ensure preventing the loss in the activity of the enzymes. The differences in the residual catalytic activities of the plasma treated and PEI modified surfaces can be explained by the differences in the strength of the binding, consequently, by the conformation of the enzymes on the surfaces. Simply, the conformational change as a result of interactions between enzyme-enzyme molecules or enzyme ionic components in PBS buffer solution during $4 \mathrm{~h}$ storage is more restricted with the presence of covalent bonding on the plasma treated surface.

\subsection{Kinetic study of immobilized SOD/CAT}

The Michaelis-Menten rate expressions can be used to describe the reaction kinetics when SOD and CAT are immobilized 
Table 2

Secondary structure of native and immobilized SOD and CAT estimated from the deconvoluted FTIR spectra.

\begin{tabular}{|c|c|c|c|c|c|}
\hline & $\begin{array}{l}\text { Secondary } \\
\text { structure } \\
\text { Assigned } \\
\text { Frequency } \\
\left(\mathrm{cm}^{-1}\right)\end{array}$ & $\begin{array}{l}\boldsymbol{\beta} \text { - } \\
\text { Sheet } \\
1620- \\
1635\end{array}$ & $\begin{array}{l}\text { Unordered } \\
\text { structure } \\
1641-1649\end{array}$ & $\begin{array}{l}\alpha- \\
\text { Helix } \\
1652- \\
1658\end{array}$ & $\begin{array}{l}\beta- \\
\text { Turn } \\
1660- \\
1700\end{array}$ \\
\hline $\begin{array}{l}\text { Native } \mathrm{Zn-Cu}-\mathrm{SOD} \\
\quad[36]\end{array}$ & \% Content & 34 & 49 & - & 17 \\
\hline Native-CAT [37] & & 34 & 19 & 30 & 17 \\
\hline Native SOD/CAT & & 44 & 18 & 16 & 22 \\
\hline PSF-PLS-SOD/CAT & & 39 & 21 & 13 & 27 \\
\hline $\begin{array}{l}\text { PSF-SPSF-PEI-SOD/ } \\
\text { CAT }\end{array}$ & & 37 & 24 & 16 & 23 \\
\hline
\end{tabular}

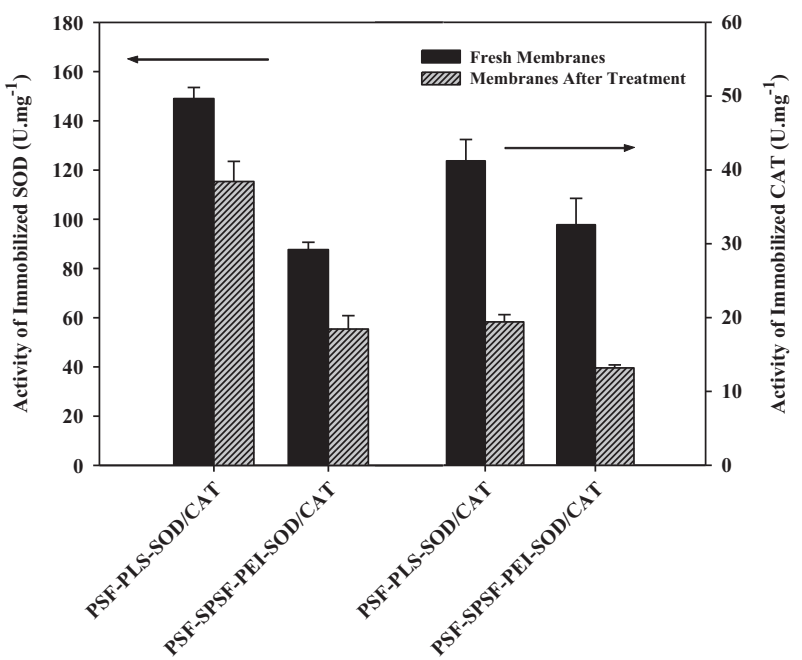

Fig. 10. Stabilities of immobilized enzymes at operating conditions $\left(T=37^{\circ} \mathrm{C}\right.$ and $\mathrm{pH}$ 7.4). Experimental conditions applied during membrane preparation and activity measurements are as follows: $C_{\mathrm{PEI}}: 0.1 \mathrm{mg} \mathrm{ml}^{-1} ; C_{\mathrm{CAT}}: 0.25 \mathrm{mg} \mathrm{ml}^{-1} ; C_{\mathrm{SOD}}$ : $0.25 \mathrm{mg} \mathrm{ml}^{-1} C_{\mathrm{H} 2 \mathrm{O} 2}: 30 \mathrm{mM}$; $C_{\text {Riboflavin }}: 2 \mu \mathrm{M}$.

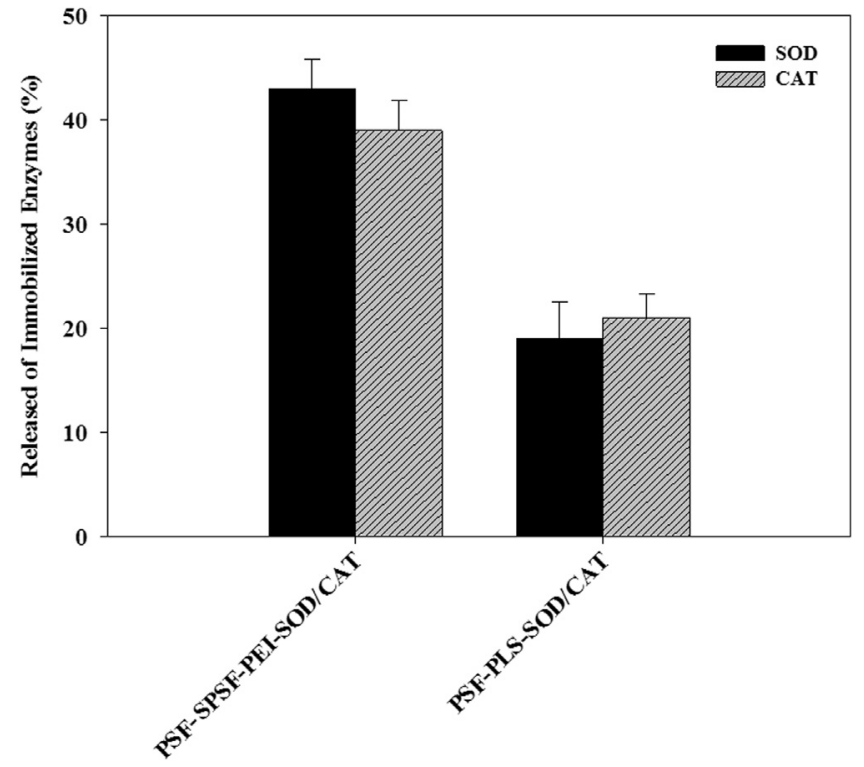

Fig. 11. Amount of SOD and CAT released at typical operating conditions $\left(T=37^{\circ} \mathrm{C}\right.$ and $\mathrm{pH}$ 7.4). separately, as given in Eqs. (3) and (4).

$$
\begin{array}{r}
\mathrm{O}_{2}^{-}+2 \mathrm{H}_{2} \mathrm{O} \stackrel{k_{\mathrm{SOD}}}{\Longrightarrow} 2 \mathrm{H}_{2} \mathrm{O}_{2} \\
2 \mathrm{H}_{2} \mathrm{O}_{2} \stackrel{k_{\mathrm{CAT}}}{\Longrightarrow} 2 \mathrm{H}_{2} \mathrm{O}+\mathrm{O}_{2} \\
r_{\mathrm{O}_{2}^{-}}=\frac{V_{\max , \mathrm{SOD}} C_{\mathrm{O}_{2}^{-}}}{K_{M, \mathrm{SOD}}+C_{\mathrm{O}_{2}^{-}}} \\
r_{\mathrm{H}_{2} \mathrm{O}_{2}}=\frac{V_{\max , \mathrm{CAT}} C_{\mathrm{H}_{2} \mathrm{O}_{2}}}{K_{M, \mathrm{CAT}}+C_{\mathrm{H}_{2} \mathrm{O}_{2}}}
\end{array}
$$

Two kinetic parameters that appear in these equations are useful to characterize an enzyme in free or immobilized forms. The first parameter, $V_{\max }$, represents the maximum reaction rate, while the Michaelis constant $K_{\mathrm{M}}$ is a measure of the strength of binding between the substrate and enzyme. When SOD and CAT are coimmobilized, each intrinsic step in the reaction sequence follows Michaelis-Menten kinetics and the rate expressions are given by;

$\mathrm{O}_{2}^{-}+2 \mathrm{H}^{+} \stackrel{k_{\mathrm{SOD}}}{\Longrightarrow} \mathrm{H}_{2} \mathrm{O}_{2} \stackrel{k_{\mathrm{CAT}}}{\Longrightarrow} \mathrm{H}_{2} \mathrm{O}+\frac{1}{2} \mathrm{O}_{2}$

$r_{O_{2}^{-}}=\frac{V_{\max , S O D} \times C_{O_{2}^{-}}}{K_{M, S O D}+C_{O_{2}^{-}}}$

$r_{\mathrm{H}_{2} \mathrm{O}_{2}}=-\frac{V_{\max , \mathrm{CAT}} C_{\mathrm{H}_{2} \mathrm{O}_{2}}}{K_{M, \mathrm{CAT}}+C_{\mathrm{H}_{2} \mathrm{O}_{2}}}+\frac{V_{\max , \mathrm{SOD}} C_{\mathrm{O}_{2}^{-}}}{K_{M, \mathrm{SOD}}+C_{\mathrm{O}_{2}^{-}}}$

Figs. 12 and 13 show the activities of free and immobilized CAT and SOD measured at various levels of $\mathrm{H}_{2} \mathrm{O}_{2}$ and riboflavin concentrations, respectively. Kinetic parameters calculated from the data in these figures are listed in Table 3.

The $V_{\max }$ values of both enzymes decreased upon immobilization onto either PEI modified or plasma treated surface due to steric hindrance of the support, hence, lower accessibility of the substrate to the active sites of the enzymes. The $K_{\mathrm{M}}$ values of immobilized enzymes were found higher than those of their free counterparts, indicating the decrease in the affinity of the enzymes to their substrate. This could be attributed to the loss in flexibility of the enzymes as a result of conformational change. The catalytic activity of CAT was not influenced by the immobilization method. On the other hand, the activity of SOD was higher on the plasma treated surface than the PEI modified surface. In the presence of CAT, inactivation of SOD by $\mathrm{H}_{2} \mathrm{O}_{2}$ was prevented since $\mathrm{H}_{2} \mathrm{O}_{2}$ was consumed as soon as it formed, consequently, the activity of SOD was enhanced by a factor of two when the enzymes were immobilized on the PEI modified surface (The $\mathrm{V}_{\max } / \mathrm{K}_{\mathrm{m}}$ values for the PSF-SPSF-PEI-SOD and PSF-SPSF-PEI-SOD membranes are $3.85 \pm 0.84$ and $6.88 \pm 1.65 \mathrm{U} \mathrm{mg}^{-1} \mathrm{mM}^{-1}$, respectively).

The enzymatic reaction rates reported are defined as observed reaction rates due to the presence of mass transfer resistance. In immobilized enzymes, substrate conversion takes place in three steps; (i) substrate transport from the bulk medium to the surface of enzyme, (ii) enzymatic conversion of the substrate into product and (iii) product transport from the surface back to the bulk medium. The influence of external mass transfer resistance on the observed reaction rates and the relative importance of the mass transfer compared to the enzymatic reaction is determined by a dimensionless number called Damköhler number, $D a_{\mathrm{II}}$. The Damköhler number is defined as the ratio of the maximum reaction rate to the maximum mass transfer rate.

$D a_{\mathrm{II}}=\frac{V_{\max }}{K_{\mathrm{L}} C_{s}}$ 
a

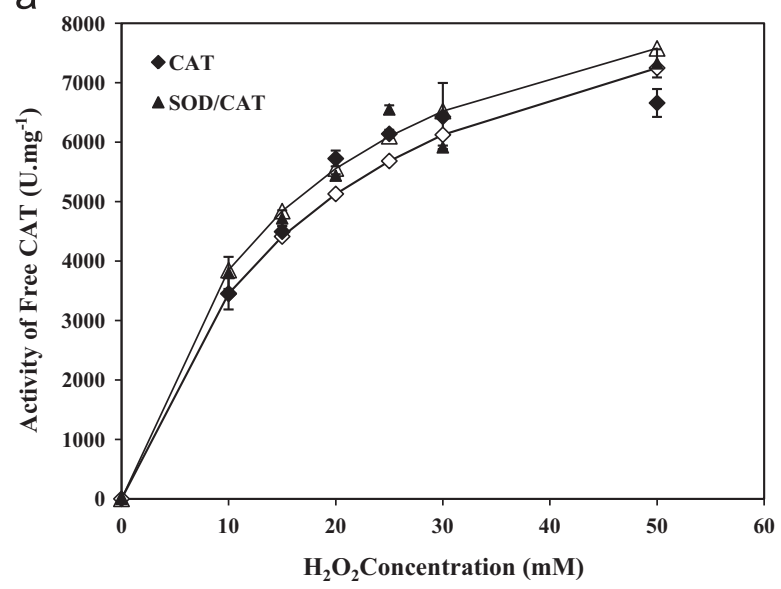

b

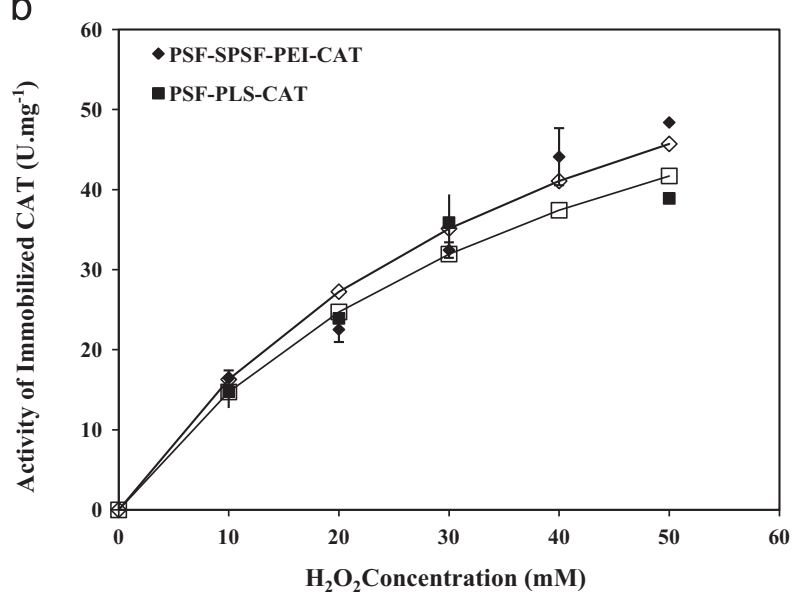

C

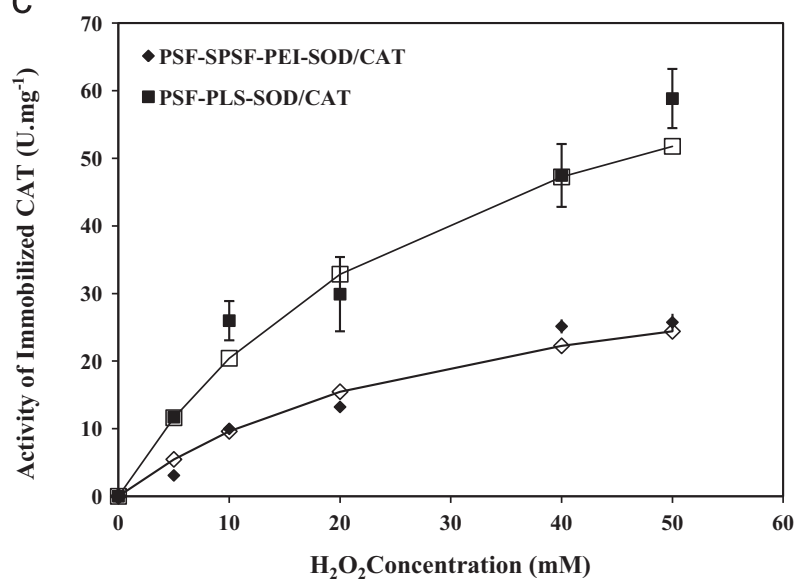

Fig. 12. Substrate concentration vs. activity of free CAT (a), immobilized CAT on the PEI modified (b) and plasma treatment (c) surfaces. Experimental conditions applied during membrane preparation and activity measurements are as follows: $C_{\mathrm{PEI}}: 0.1 \mathrm{mg} \mathrm{ml}^{-1} ; C_{\mathrm{CAT}}: 0.25 \mathrm{mg} \mathrm{ml}^{-1} ; C_{\mathrm{H} 2 \mathrm{O} 2}: 30 \mathrm{mM}$. Experiments were conducted with CPEI-initial: $0.1 \mathrm{mg} \mathrm{ml}^{-1}$; Cenzyme-initial: $0.25 \mathrm{mg} \mathrm{ml}^{-1}$ and $\mathrm{CH}_{2} \mathrm{O}_{2}$ : $30 \mathrm{mM}$.

where $V_{\max }\left(\mathrm{mmol} \mathrm{cm}^{-2} \mathrm{~s}^{-1}\right)$ is the maximum reaction rate; $K_{\mathrm{L}}$ $\left(\mathrm{cm} \mathrm{s}^{-1}\right)$ is the liquid phase mass transfer coefficient of substrate and $C_{\mathrm{S}}\left(\mathrm{mmol} \mathrm{ml}^{-1}\right)$ is the concentration of substrate at the surface of the enzyme.

The change in Damköhler number with respect to the stirring rate for native and immobilized CAT is shown in Table 4. Experimentally, the same activities were measured for immobilized CAT when the
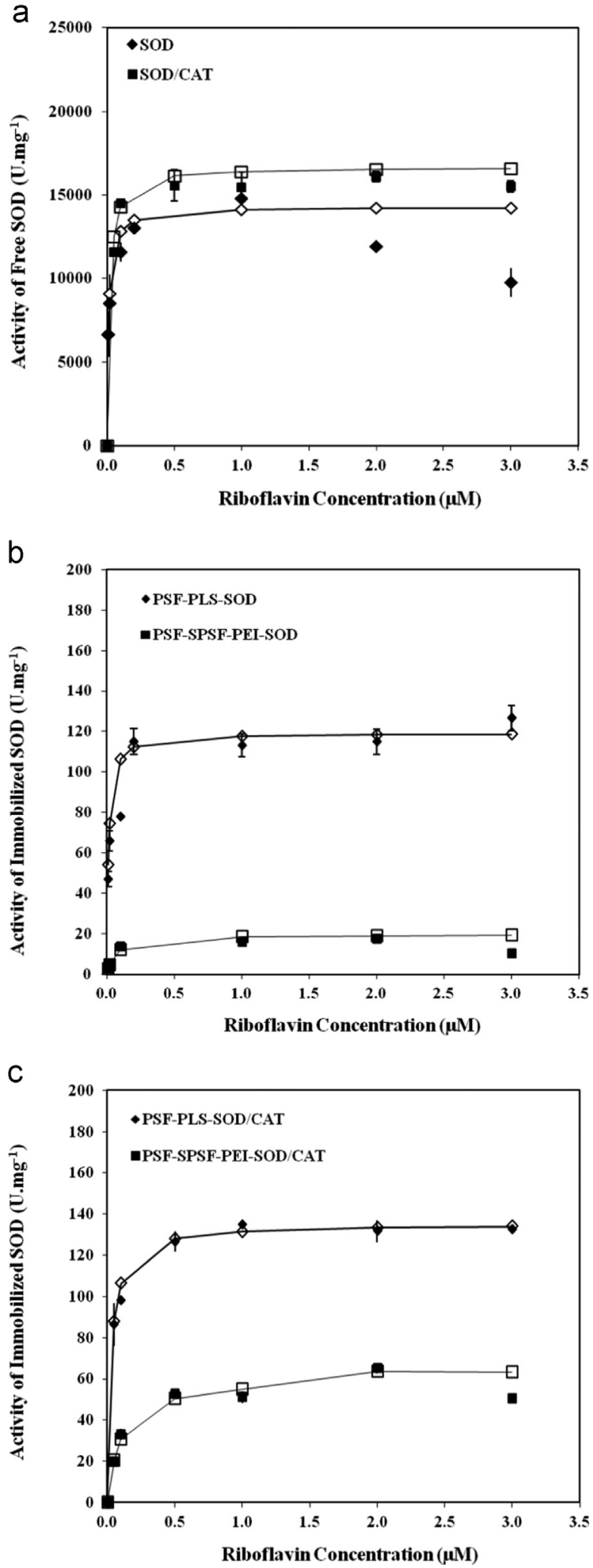

Fig. 13. Substrate concentration vs activity of free SOD (a), immobilized on the PE modified (b) and plasma treated (c) surfaces. Experimental conditions applied during membrane preparation and activity measurements are as follows: $C_{\mathrm{PEI}}$ : $0.1 \mathrm{mg} \mathrm{ml}^{-1} ; C_{\mathrm{SOD}}: 0.25 \mathrm{mg} \mathrm{ml}^{-1} ; C_{\text {Riboflavin }}: 2 \mu \mathrm{M}$.

stirring rate was increased from 600 to $800 \mathrm{rpm}$. Consistent with this observation, Damköhler numbers calculated to be smaller than 1 at these stirring rates indicate negligible mass transfer limitations. 
Table 3

Michealis-Menten kinetic parameters of native and immobilized CAT and SOD.

\begin{tabular}{|c|c|c|c|c|c|c|}
\hline \multirow[t]{2}{*}{ Membrane Code } & \multicolumn{3}{|c|}{ Michealis-Menten kinetic parameters of CAT } & \multicolumn{3}{|c|}{ Michealis-Menten kinetic parameters of SOD } \\
\hline & $V_{\max }\left(\mathrm{U} \mathrm{mg}^{-\mathbf{1}}\right)$ & $K_{M}(\mathbf{m M})$ & $V_{\max } / K_{M}\left(\mathrm{U} \mathrm{mg}^{-1} \mathrm{mM}^{-1}\right)$ & $V_{\max }\left(\mathrm{U} \mathrm{mg}^{-\mathbf{1}}\right)$ & $K_{\mathbf{M}}(\mathbf{m M})$ & $V_{\max } / K_{M}\left(\mathrm{U} \mathrm{mg}^{-1} \mathrm{mM}^{-1}\right)$ \\
\hline Native CAT & $11579 \pm 1168$ & $22.7 \pm 4.4$ & $510 \pm 111$ & - & - & - \\
\hline PSF-SPSF-PEI-CAT & $83.8 \pm 10.1$ & $49.1 \pm 10.2$ & $1.71 \pm 0.41$ & - & - & - \\
\hline PSF-PLS-CAT & $80.9 \pm 5.8$ & $38.7 \pm 5.2$ & $2.09 \pm 0.32$ & - & - & - \\
\hline Native SOD & - & - & - & $14080 \pm 489$ & $1.3 \pm 0.2$ & $10839 \pm 1708$ \\
\hline PSF-SPSF-PEI-SOD & - & - & - & $18.1 \pm 0.8$ & $4.7 \pm 1.0$ & $3.85 \pm 0.84$ \\
\hline PSF-PLS-SOD & - & - & - & $117.3 \pm 5.5$ & $1.8 \pm 0.5$ & $65.17 \pm 18.36$ \\
\hline Native SOD-CAT & $13238 \pm 1354$ & $25.9 \pm 4.5$ & $511 \pm 103$ & $15983 \pm 250$ & $1.6 \pm 0.3$ & $9989 \pm 1880$ \\
\hline PSF-SPSF-PEI-SOD/CAT & $91.7 \pm \overline{16.1}$ & $45.9 \pm 14.2$ & $1.99 \pm 0.71$ & $70.9 \pm \overline{3} .8$ & $10 . \overline{3} \pm 2.4$ & $6.88 \pm 1.65$ \\
\hline PSF-PLS-SOD/CAT & $117.3 \pm 16.0$ & $33.9 \pm 9.9$ & $3.46 \pm 1.11$ & $142.2 \pm 6.3$ & $3.1 \pm 0.3$ & $45.87 \pm 4.88$ \\
\hline
\end{tabular}

Table 4

The change in Damköhler numbers with respect to the stirring rate for the native and immobilized CAT and SOD.

\begin{tabular}{lllll}
\hline \multirow{2}{*}{ Sample } & \multicolumn{2}{l}{ Stirring rate } & \\
\cline { 2 - 5 } & $\mathbf{6 0 0} \mathbf{~ r p m}$ & $\mathbf{8 0 0} \mathbf{~ r p m}$ & $\mathbf{6 0 0} \mathbf{~ r p m}$ & $\mathbf{8 0 0} \mathbf{~ r p m}$ \\
\hline Native CAT & 0.02 & 0.02 & - & - \\
PSF-SPSF-PEI-CAT & 0.06 & 0.05 & - & - \\
PSF-PLS-CAT & 0.06 & 0.05 & - & - \\
Native SOD & - & - & 328 & 279 \\
PSF-SPSF-PEI-SOD & - & - & 62 & 52 \\
PSF-PLS-SOD & - & - & 336 & 285 \\
Native SOD-CAT & 0.02 & 0.02 & 308 & 262 \\
PSF-SPSF-PEI-SOD/CAT & 0.04 & 0.03 & 313 & 266 \\
PSF-PLS-SOD/CAT & 0.07 & 0.06 & 336 & 285 \\
\hline
\end{tabular}

SOD, known as the diffusion-controlled enzyme, is defined as a superefficient enzyme with $k_{\text {cat }} / K_{\mathrm{M}}$ of $1.7 \times 10^{10} \mathrm{M}^{-1} \mathrm{~s}^{-1}\left(k_{\mathrm{cat}}=[\mathrm{E}]\right.$ $V_{\max }$ where [E] is the enzyme concentration) the highest catalytic rate ever reported for any enzyme [41]. As seen in Table 4, the Damköhler numbers for all SOD immobilized membranes and free SOD are much higher than 1 for both stirring rates $(600 \mathrm{rpm}$ and $800 \mathrm{rpm}$ ). A sharp increase in the activity of immobilized SOD to the maximum reaction rate at low substrate concentrations (Fig. 13a and b) and the degree of conversion, which is about 0.9 for all cases, suggest that that the reaction is in the mass transfer limited region. Mass transfer resistance is usually minimized by high stirring rates. On the other hand, this might cause partial or complete denaturation and the detachment of the enzyme. It is clear that SOD enzyme in free or immobilized form cannot work in the reaction-limited regime.

\subsection{Protein adsorption capacity of membranes}

The amount of plasma protein adsorbed on the membranes was determined since it is critical for blood-material interactions followed by an increase in the levels of ROS. Fig. 14 shows that the PSF-PLS membrane generated through plasma polymerization of PSF with ethylenediamine reduced protein adsorption by $53 \%$ with respect to PSF membrane. In many studies, it is reported that plasma polymerization of hydrophilic monomeric gases at low temperature reduced protein fouling due to the formation of polar groups on the surface [42]. The water contact angle values (Fig. 5) illustrated the enhanced hydrophilic character of the PSF surface after plasma treatment. Lower amount of protein adsorbed onto the plasma treated PSF surface than the PSF-SPSF membrane is due to a smoother and a much more neutral membrane surface of PSF. The PSF-SPSF membrane is highly negatively charged with $\mathrm{SO}_{3}^{-}$groups which favor protein adsorption by electrostatic

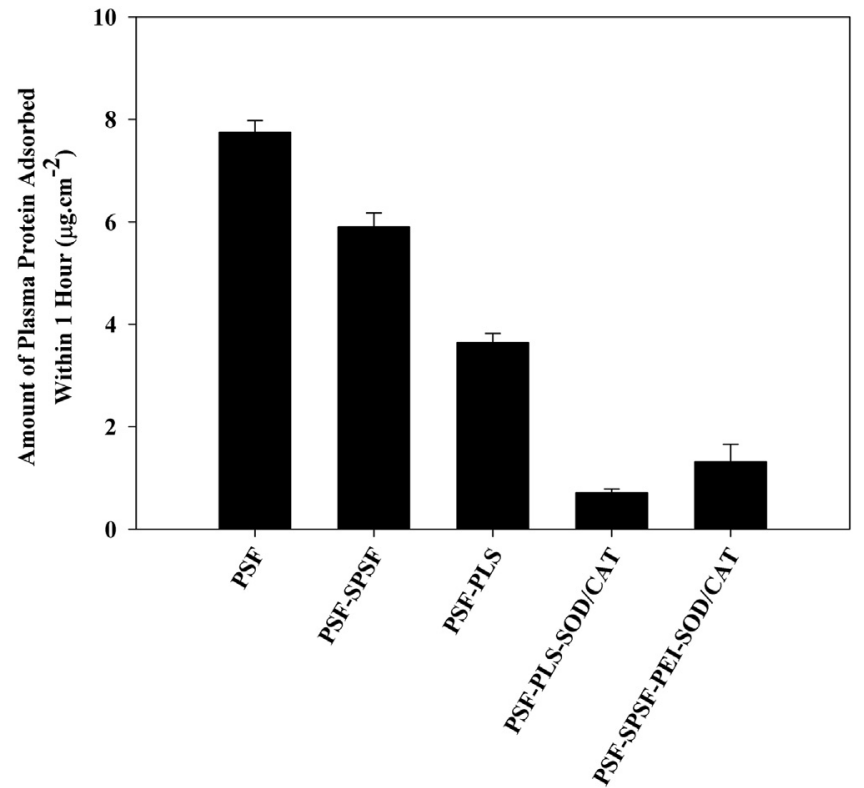

Fig. 14. The amount of blood plasma proteins adsorbed onto unmodified and modified PSF membranes.

interactions [43] while plasma treated membranes are neutral due to non-protonated $\mathrm{NH}_{2}$ groups. The improvement of the membrane hydrophilicity by enzyme immobilization weakened the protein surface hydrophobic interactions, thus, significantly decreased the protein adsorption. SOD/CAT immobilization on the plasma treated membrane created a surface which shows slightly higher resistance to protein adsorption compared with the surface generated by immobilizing the same enzymes on the PEI adsorbed PSF-SPSF membrane (Fig. 14). This is not only due to much smoother surface of the plasma treated membrane, but also to the lower protein adsorption capacity of the surface underneath the enzyme layer (PSF-PLS) than that on the PSF-SPSF-PEI surface.

\subsection{Platelet adhesion and activation}

Several studies have suggested that ROS can significantly affect platelet responses including platelet surface marker expression and platelet aggregation [44]. Fig. 15 shows that the plasma treatment and SOD/CAT immobilization remarkably decreased the platelet activation. The suppression of platelet activation on all of the modified membranes prepared in this study is most likely to come from diminished protein adsorption. In addition, it was reported that when SOD induces the platelet activation, CAT fully prevents SOD-dependent platelet activation [45-46].

We have also investigated the morphology and activation of adhered platelets on the membranes through SEM pictures. Fig. 16 
illustrates that platelet adhesion and activation were observed only on the PSF-SPSF membrane. The loss in the discoid shape of the platelets indicated the beginning of activation on this membrane.

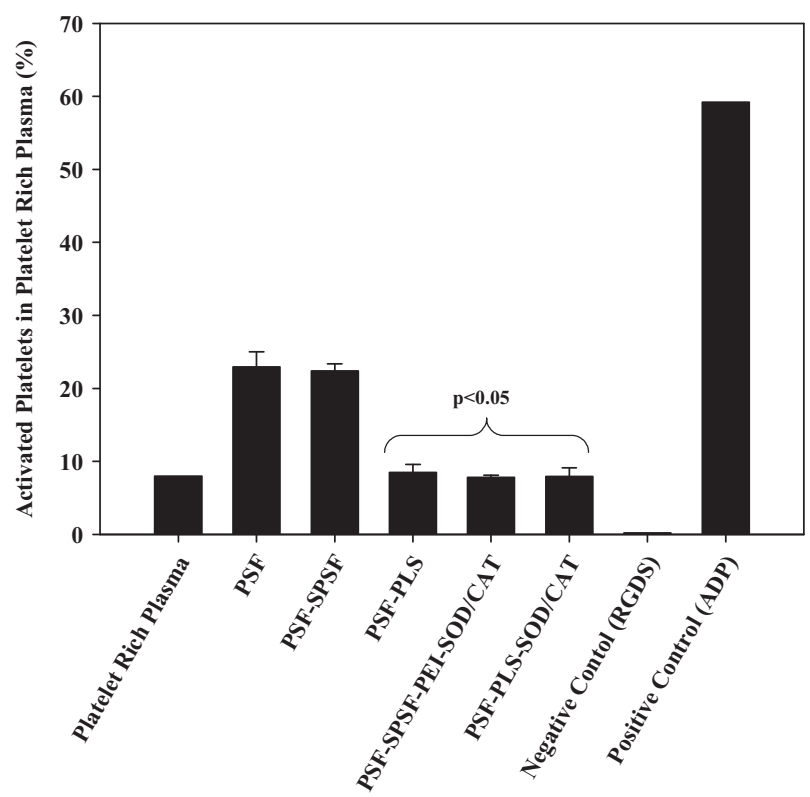

Fig. 15. Amount of platelet activation on the unmodified and modified PSF membranes.

\subsection{Inhibition of ROS in plasma}

The in vitro antioxidant activities of SOD/CAT coated membranes were investigated in relevance to the inhibition of ROS in blood. Fig. 17 shows that the SOD/CAT immobilized on the membranes significantly suppressed the ROS generation (expressed as CL counts of $\mathrm{HOCl}$ ) in blood. The SOD/CAT immobilized on either PEI modified or plasma treated surfaces did not cause a significant difference $(p>0.05)$ in the CL counts of $\mathrm{HOCl}$.

The enzyme couple catalyzed the conversion of superoxide anion to water and oxygen.

As a result of the reduction in the $\mathrm{O}_{2}^{-}$and $\mathrm{H}_{2} \mathrm{O}_{2}$ levels in blood, oxidative balance is restored in favor of the antioxidants in blood. Consequently, the increased level of antioxidants can dissipate the other ROS, such as $\mathrm{HOCl}$, in blood.

\subsection{Activated partial thromboplastin time (APTT)}

The APTT values for SOD/CAT immobilized membranes were measured since the decreased adsorption of blood proteins and platelet activation on these membranes and inhibition of ROS production raised the possibility that these membranes could also prolong the coagulation time (APTT). Compared to the PSF, PSF-SPSF and the control membranes, the SOD/CAT immobilization provided significantly longer APTT values regardless of the immobilization method (Table 5). Although enzyme immobilization caused lower protein adsorption and platelet activation when the surface was activated with plasma treatment, the choice of immobilization method did not significantly affect the ability of the membranes in inhibiting the ROS formation (APTT values for a

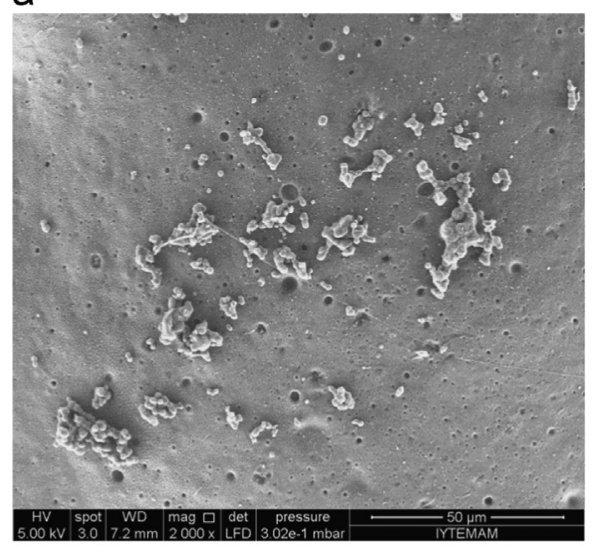

C

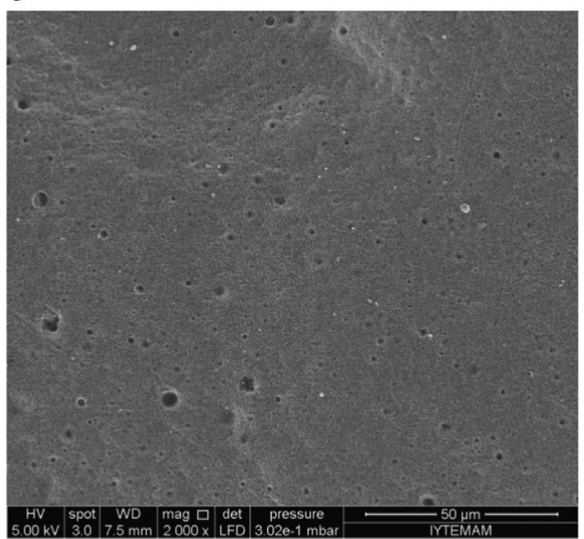

b

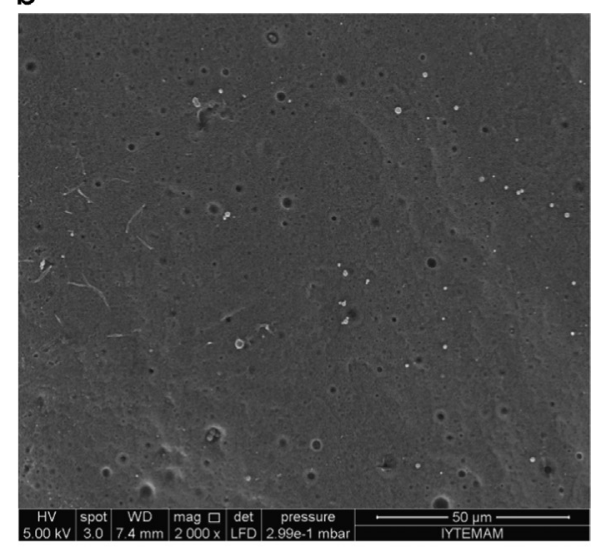

d

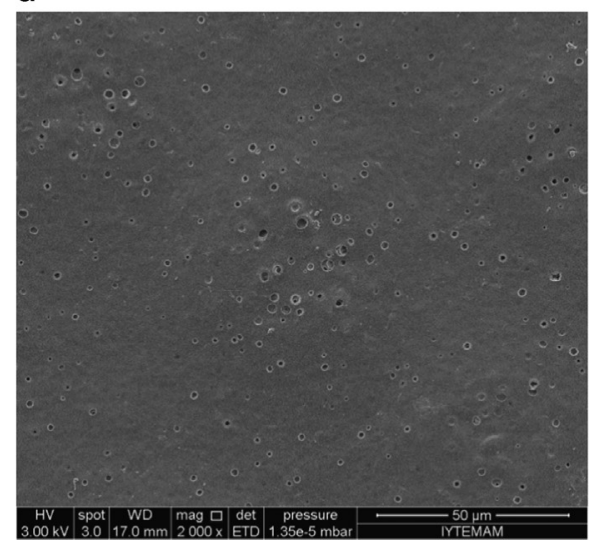

Fig. 16. The SEM pictures of (a) PSF-SPSF (b) PSF-PLS (c) PSF-PLS-SOD/CAT and (d) PSF-SPSF-PEI-SOD/CAT membranes after incubating with platelet rich plasma (PRP) for 25 min, magnification $2000 \times$. 


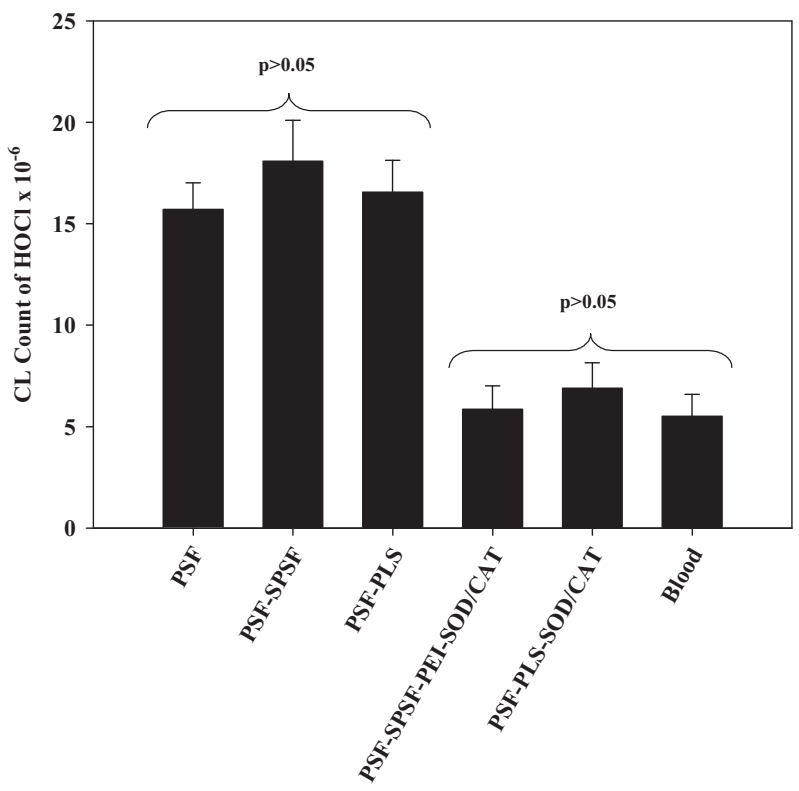

Fig. 17. The inhibition $\mathrm{HOCl}$ in blood by unmodified and modified membranes.

Table 5

APTT values for unmodified and modified PSF membranes and \% live peripheral mononuclear blood cells after $4 \mathrm{~h}$ treatment with unmodified and modified PSF membranes.

\begin{tabular}{lll}
\hline Membrane Code & APTT (s) & Live cell \% \\
\hline Control & $39 \pm 2$ & 100 \\
PSF & $36 \pm 3$ & $98.7 \pm 1.1$ \\
PSF-SPSF & $37 \pm 4$ & $97.9 \pm 0.9$ \\
PSF-PLS & $49 \pm 3$ & $98.1 \pm 0.7$ \\
PSF-SPSF-PEI-SOD/CAT & $67 \pm 4$ & $98.3 \pm 1.2$ \\
PSF-PLS-SOD/CAT & $62 \pm 3$ & $99.4 \pm 0.2$ \\
\hline
\end{tabular}

the PSF-SPSF-PEI-SOD/CAT and PSF-PLS-SOD/CAT membranes are $67 \pm 4 \mathrm{~s}$ and $62 \pm 3 \mathrm{~s}$, respectively). This result suggests that in order to prolong the coagulation time the suppression of ROS formation is a more effective strategy than improvement of antifouling by SOD/CAT immobilization.

\subsection{Cytotoxicity of membranes}

The cytotoxicities of pure SOD and CAT were not measured since they are the most important blood antioxidants with a concentration of $548 \mu \mathrm{g} \mathrm{l}^{-1}$ in blood serum (240 $\mathrm{mg} \mathrm{l}^{-1}$ in erythrocytes in blood) [47]. While SOD can be very toxic in the presence of iron in blood, it is non-toxic when used in combination with CAT or another peroxidase [48]. Cytotoxicity studies conducted with the SOD/CAT immobilized membranes have shown that the viability of peripheral mononuclear blood cells (PMBC) after 4 h-treatment with unmodified and modified membranes is nearly $100 \%$ (Table 5 ). The excellent cell viability of the modified membranes confirms that the SOD/CAT immobilization does not have a significant negative effect on the non-toxic property of the unmodified PSF membrane.

The positively charged PEI is known to be toxic, therefore, we determined amount of PEI released from PSF-SPSF-PEI membrane into PBS ( $\mathrm{pH} 7.4$, including $137 \mathrm{mM} \mathrm{NaCl}$ and $2.7 \mathrm{mM} \mathrm{KCl}$ ) at $37^{\circ} \mathrm{C}$. At the end of $4 \mathrm{~h}$, PEI eluted from this membrane $(3.3 \mu \mathrm{g} \mathrm{PEI} / \mathrm{ml}$ blood) was found to be lower than the toxic dosage of branched PEI $(10 \mu \mathrm{g} / \mathrm{ml}$ cell $)$ as reported by Wen et al. [49]. Obviously, higher release rate is expected during a real hemodialysis process under high flow rate and it can be roughly estimated by comparing the mass transfer coefficients under static and dynamic flow conditions. The mass transfer coefficient of a solute in blood $\left(k_{\mathrm{B}}\right)$ can be predicted from the following equation [50].

$k_{\mathrm{B}}=\frac{4.3 D_{\text {eff }}}{d} \quad D_{\text {eff }}=\left(0.53 D_{i j}+5.292 \times 10^{-9} \dot{\gamma}_{w}\right)$

where $d$ is the inner diameter of hollow fiber and $D_{\text {eff }}$ is the effective diffusion coefficient of the solute in blood. The effective diffusion coefficient consists of two terms. The first term represents the reduction in the diffusion coefficient $\left(D_{i j}\right)$ due to presence of red blood cells. The second term represents mixing which is proportional to the shear rate $\left(\dot{\gamma}_{w}\right)$ and it becomes zero when there is no flow. The ratio of mass transfer coefficient of the solute under dynamic and static conditions can then be expressed as:

$\frac{k_{B, \text { with flow }}}{k_{B, \text { without flow }}}=1+\frac{5.292 \times 10^{-9} \dot{\gamma}_{\mathrm{w}}}{0.53 D_{i j}}$

Using shear rate value of $250 \mathrm{~s}^{-1}$ reported for blood flow in a hollow fiber dialyzer and the albumin diffusion coefficient at $37{ }^{\circ} \mathrm{C}$ $\left(6.34 \times 10^{-7} \mathrm{~cm}^{2} / \mathrm{s}\right)$ as an approximate value for the diffusion coefficient of PEI in blood, the ratio was calculated around 5 [50]. This means the release rate of PEI from the membrane under blood flow will be approximately 5 times higher than the rate when there is no flow. According to this estimation, released PEI ( $15 \mu \mathrm{g} / \mathrm{ml}$ blood) exceeds the limit of toxic dosage, on the other hand, one can expect lower amount eluted from the enzyme immobilized membrane (PSF-SPSF-PEI-SOD/CAT) since in this case elution of PEI will mainly take place after the upper enzyme layer is lost.

We have also determined cytotoxicity of the PEI coated PSF membrane (PSF-SPSF-PEI) after $48 \mathrm{~h}$ of incubation to allow nearly maximum possible PEI elution from this membrane. Even after such a long incubation period, the viability of cells did not drop below $85 \pm 3 \%$. As a result, we can conclude that even if the membrane releases PEI into the blood stream, it is not expected to observe significant toxicity on PBMCs under high blood flow conditions.

\subsection{Transport and mechanical properties of the membranes}

It is known that plasma treatment may cause etching on the surface of the membrane [51]. This may result in the disruption of the dense skin layer and the semi-permeable character of the membrane. According to the data in Fig. 18, permeabilities of the solutes did not change significantly $(p>0.05)$ after plasma treatment suggesting that there is no etching on the PSF-PLS membrane which is also proven by SEM and AFM pictures (Figs. 6-8). SOD/CAT immobilization did not change the permeation characteristics of the unmodified PSF membranes since neither the bulk structure of the support membrane nor the thickness of dense skin layer was affected by enzyme immobilization.

Mechanical properties of the unmodified and modified membranes are listed in Table 6. Plasma treatment caused a slight decrease in maximum tensile strength of the PSF membrane while deposition of SOD/CAT on either the plasma treated or PEI modified membranes did not significantly change the mechanical properties $(p>0.05)$.

\section{Conclusion}

We have developed PSF based hemodialysis membranes modified with co-immobilized SOD/CAT enzymes. Adsorption of enzymes on plasma treated surface provided stronger attachment with covalent bonding than that with ionic bonding on PEI modified surfaces. On the other hand, enzymes immobilized on these surfaces controlled 


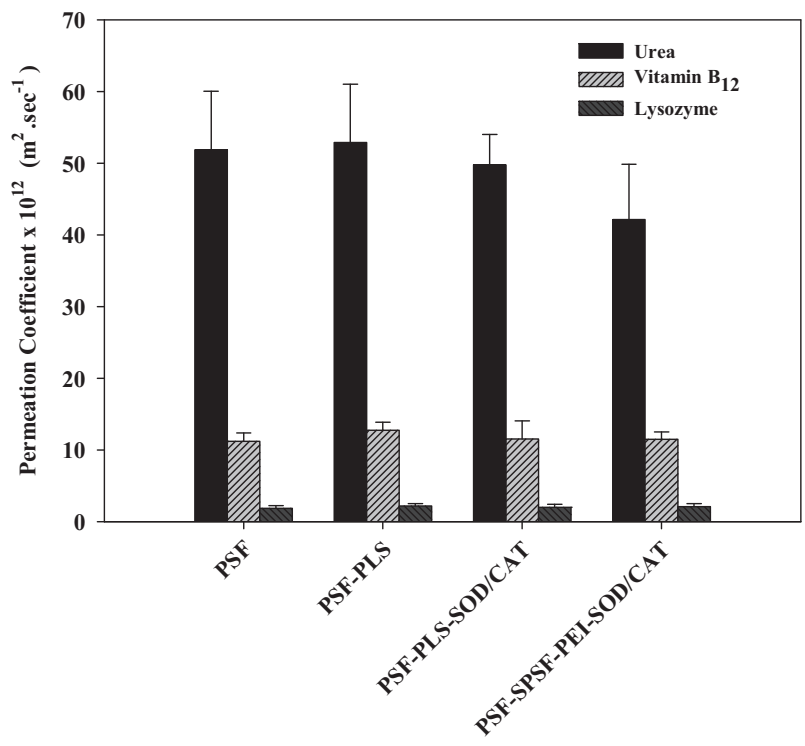

Fig. 18. The permeation coefficient of urea, vitamin B12 and lysozyme through unmodified and modified PSF membranes. *Permeation coefficients of the solutes through the membranes are not statistically different from each other $(p>0.05)$.

\section{Table 6}

Mechanical properties of the unmodified and modified PSF membranes.

\begin{tabular}{lll}
\hline Membrane code & $\begin{array}{l}\text { Maximum tensile stress } \\
(\mathbf{M P a})\end{array}$ & $\begin{array}{l}\text { Young modulus } \\
\text { (MPa) }\end{array}$ \\
\hline PSF & $2.78 \pm 0.22$ & $39.82 \pm 5.97$ \\
PSF-SPSF & $2.25 \pm 0.18$ & $50.25 \pm 7.54$ \\
PSF-PLS & $2.39 \pm 0.21$ & $49.72 \pm 5.51$ \\
PSF-PLS-SOD/CAT & $2.26 \pm 0.17$ & $51.19 \pm 7.73$ \\
PSF-SPSF-PEI-SOD/ & $2.31 \pm 0.19$ & $43.27 \pm 4.11$ \\
$\quad$ CAT & & \\
\hline
\end{tabular}

platelet activation and the ROS levels in blood plasma at similar rates. All modified membranes displayed higher blood compatibilities than native PSF membranes. This enhanced hemocompatibility correlates well with reduced protein adsorption capacities of the modified membranes as a consequence of their increased hydrophilic properties. Hemodialysis induced oxidative stress is still a problem in clinical applications and the SOD/CAT immobilization proposed in this study could become an attractive alternative for producing functional membranes that are capable of suppressing oxidative stress. Considering the fact that SOD and CAT enzymes are known as the most important antioxidant couple in blood, our modified membranes have the great potential to lead to favorable results also in in vivo studies.

\section{Acknowledgments}

We gratefully acknowledge financial support by L'Oreal Turkey Women in Science Program and Izmir Institute of Technology (Grant no. 2010IYTE03). We also acknowledge Izmir Institute of Technology Biotechnology and Bioengineering and Material Research Centers for providing facilities for performing the in vitro blood compatibility tests and SEM analysis.

\section{References}

[1] M. Mydlik, K. Derzsiova, O. Racz, A. Sipulova, E. Lovasova, J. Petrovicova, A modified diayzer with vitamin E and antioxidant defense parameters, Kidney Int. 59 (2001) 144-147.
[2] G. Clermont, L.S. Sandrine, J.F.C. Cabanne, G. Motte, J.C. Guilland, D. Chevet L. Rochette, Vitamin E-coated dialyzer reduces oxidative stress in hemodialysis patient, Free Radic. Biol. Med. 31 (2001) 233-241.

[3] K.I. Yamamato, M. Matsuda, M. Okuoka, T. Yakushiji, M. Fukuda, T. Miyasaka, Y. Matsumoto, K. Sakai, Antioxidation property of vitamin E-coated polysulfone dialysis membrane and recovery of oxidized vitamin E by vitamin C treatment, J. Membr. Sci. 302 (15) (2007) 115-118.

[4] F.C. Kung, M.C. Yang, Effect of conjugated linoleic acid grafting on the hemocompatibility of polyacrylonitrile membrane, Polym. Adv. Technol. 17 (2006) 419-425.

[5] F.C. Kung, M.C. Yang, The effect of covalently bonded conjugated linoleic acid on the reduction of oxidative stress and blood coagulation for polysulfone hemodialyzer membrane, Int. J. Biol. Macromol. 38 (2006) 157-164.

[6] F.C. Kung, M.C. Yang, Effect of conjugated linoleic acid immobilization on the hemocompatibility of cellulose acetate membrane, Colloids Surf. B: Biointerfaces 47 (2006) 36-42.

[7] F.C. Kung, M.C. Yang, The reduction of oxidative stress, anticoagulation of platelets, and inhibition of lipopolysaccharide by conjugated linoleic acid bonded on a polysulfone membrane, Polym. Adv. Technol. 18 (2007) 286-291.

[8] C. Neelakandan, T. Chang, T. Alexander, L. Define, M. Evancho-Chapman, T. Kyu, In vitro evaluation of antioxidant and anti-inflammatory properties of genistein-modified hemodialysis membranes, Biomacromolecules 12 (2011) 2447-2455.

[9] F.Y. Mahlicli, S.A. Altinkaya, Immobilization of alpha lipoic acid onto polysulfone membranes to suppress hemodialysis induced oxidative stres, J. Membr. Sci. 449 (2014) 27-37.

[10] S. Giovagnoli, P. Blasi, M. Ricci, C. Rossi, Biodegradable microspheres as carriers for native superoxide dismutase and catalase delivery, AAPS PharmSciTech 5 (2004) 1-9.

11] I. Pastor, A. Salinas-Castillo, R. Esquembre, R. Mallavia, CR Mateo, Multienzymatic system immobilization in sol-gel slides: fluorescent superoxide biosensors development, Biosens. Bioelectron. 25 (2010) 1526-1529.

[12] R. Villalong, R. Cao, A. Fragoso, A.E. Damiao, D. Pedro, J.O. Caballero, Supramolecular assembly of cyclodextrin-modified gold nanoparticles and $\mathrm{Cu}, \mathrm{Zn}$ superoxide dismutase on catalase, J. Mol. Catal. B: Enzym. 35 (2005) 79-85.

[13] M.M. Bilek, D.R. McKenzie, Plasma modified surfaces for covalent immobilization of functional biomolecules in the absence of chemical linkers: towards better biosensors and a new generation of medical implants, Biophys. Rev. 2 (2010) 55-65.

[14] Y. Yin, N.J. Nosworthy, B. Gong, D. Bax, A. Kondyurin, D.R. McKenzie, M.M. Bilek, Plasma polymer surfaces compatible with a CMOS process for direct covalent enzyme immobilization, Plasma Process. Polym. 6 (2009) $68-75$.

[15] K.S. Siow, L. Britcher, S. Kumar, H.J. Griesser, Plasma Methods for the generation of chemically reactive surfaces for biomolecule immobilization and cell colonization - a review, Plasma Process. Polym. 3 (2006) 392-418.

[16] Q.T. Nguyen, Z. Ping, T. Nguyen, P. Rigal, Simple method for immobilization of biomacromolecules onto membranes of different types, J. Membr. Sci. 213 (2003) 85-95.

[17] V. Smuleac, D.A. Butterfield, D. Bhattacharyya, Layer-by-layer-assembled microfiltration membranes for biomolecule immobilization and enzymatic catalysis, Langmuir 22 (2006) 10118-10124.

[18] S. Datta, C. Cecil, D. Bhattacharyya, Functionalized membranes by layer-by layer assembly of polyelectrolytes and in situ polymerization of acrylic acid for applications in enzymatic catalysis, Ind. Eng. Chem. Res. 47 (2008) 4586-4597.

[19] Y. Wang, F. Caruso, Macroporous zeolitic membrane bioreactors, Adv. Funct. Mater. 14 (2004) 1012-1018.

[20] A. Yu, Z. Liang, F. Caruso, Enzyme multilayer-modified porous membranes as biocatalysts, Chem. Mater. 17 (2005) 171-175.

[21] S. Guedidi, Y. Yurekli, A. Deratani, P. Dejardin, C. Innocent, S.A. Altinkaya, S. Roudesli, A. Yemenicioglu, Effect of enzyme location on activity and stability of trypsin and urease immobilized on porous membranes by using layer-bylayer self-assembly of polyelectrolyte, J. Membr. Sci. 365 (2010) 59-67.

[22] M. Erol, H. Du, S. Sukhishvili, Control of specific attachment of proteins by adsorption of polymer layers, Langmuir 19/22 (26) (2006) 11329-11336.

[23] Q.T. Nguyen, K. Glinel, M. Pontie, Z. Ping, Immobilization of biomacromolecules onto membranes via an adsorbed monolauyer: an insight into the mechanism, J. Membr. Sci. 232 (2004) 123-132.

[24] E. Akdoğan, M. Mutlu, Generation of amphoteric surfaces via glow-discharge technique with single precursor and the behavior of bovine serum albumin at the surface, Colloids Surf. B: Biointerfaces 89 (2012) 289-294.

[25] H.A. Güleç, A. Topacli, C. Topacli, N. Albayrak, M. Mutlu, Modification of cellulose acetate membrane via low-pressure plasma polymerisation for sugar separation applications: Part I: membrane development and characterization, J. Membr. Sci. 350 (2010) 310-321.

[26] İ. Karamollaoğlu, H.A. Öktem, M. Mutlu, QCM-based DNA biosensor for detection of genetically modified organisms, Biochem. Eng. J 44 (2009) $142-150$.

[27] D. Çökeliler, H. Caner, J. Zemek, A. Choukourov, H. Biederman, M. Mutlu, A plasma polymerization technique to overcome cerebrospinal fluid shunt infections, Biomed. Mater.: Mater. Tissue Eng. Regen. Med. 2 (1) (2007) 39-47.

[28] M. Mutlu, S. Mutlu, M.F. Rosenberg, J. Kane, M.N. Jones, P. Vadgama, Matrix surface modification by plasma polymerization for enzyme immobilization, J. Mater. Chem. 1 (3) (1991) 447-450.

[29] M. Mutlu, E. Piskin, Blood plasma proteins on polyurethane and alkylsiloxane plasma-treated polyurethane surfaces. Dynamic approach by stimulus- 
response technique. Part 2. Evaluation of adsorption data by moment technique, Med. Biol. Eng. Comput. 28 (1990) 232-236.

[30] M.M. Bradford, A rapid and sensitive method for the quantitation of microgram quantities of protein utilizing the principle of protein-dye binding, Anal. Biochem. 72 (1976) 248-254.

[31] M.C. Yang, W.C. Lin, Surface modification and blood compatibility of polyacrylonitrile membrane with immobilized chitosan-heparin conjugate, J. Polym. Res. 9 (2002) 201-206.

[32] L.J. Langsdorf, A.L. Zydney, Diffusive and convective solute transport through hemodialysis membranes: a hydrodynamic analysis, J. Biomed. Mater. Res. 28 (1994) 573-582.

[33] O. Alptekin, S.S. Tukel, D. Yıldırım, D. Alagoz, Characterization and properties of catalase immobilized onto controlled pore glass and its application in batch and plug-flow type reactors, J. Mol. Catal. B: Enzym. 58 (2009) 124-131.

[34] O. Alptekin, S.S. Tukel, D. Yıldırım, D. Alagoz, Immobilization of catalase onto Eupergit C and its characterization, J. Mol. Catal. B: Enzym. 64 (2010) 177-183.

[35] C. David, C. d'Andrea, E. Lancelota, J. Bochterle, N. Guillot, B. Fazio, O.M. Maragò, A. Sutton, N. Charnaux, F. Neubrech, A. Pucci, P.G. Gucciardi, M.L. de la Chapelled, Raman and IR spectroscopy of manganese superoxide dismutase, a pathology biomarker, Vib. Spectrosc. 62 (2012) 50-58.

[36] W.Y. Sun, J.L. Fang, M. Chen, P.Y. Xia, W.X. Tang, Secondary structure of copper zinc superoxide dismutase dependent on metal ions investigated by Fourier transform IR spectroscopy, Biopolymers 42 (1997) 297-303.

[37] J.A. Tainer, E.D. Getzoff, J.S. Richardson, D.C. Richardson, Structure and mechanism of copper, zinc superoxide dismutase, Nature 306 (1983) 284-287.

[38] J. Houli, L. Changling, S. Zhanjun, M. Sun, D. Zehan, FTIR study of the catalytic mechanism of catalase on the hydrolysis of soman, Acta Biophys. Sin. 12 (1996) 200-220.

[39] K. Griebenow, A.M. Klibanov, Lyophilization-induced changes in the secondary structure of proteins, Proc. Natl. Acad. Sci. 92 (1995) 10969-10976.

[40] A.L. Lehninger, D.L. Nelson, M.M. Cox, Principles of Biochemistry, 2nd edition, Worth Publishers, U.S.A., NewYork (1993) 111-133.
[41] M.E. Stroppolo, A. Pesce, M. Falconi, P. O’Neill, M. Bolognesi, A. Desideri, Single mutation at the intersubunit interface confers extra efficiency to $\mathrm{Cu}, \mathrm{Zn}$ superoxide dismutase, Fed. Eur. Biochem. Soc. 483 (1) (2000) 17-20.

[42] M. Ulbricht, G. Belfort, Surface modification of ultrafiltration membranes by low temperature plasma II. Graft polymerization onto polyacrylonitrile and polysulfone, J. Membr. Sci. 111 (1996) 193-215.

[43] E. Ostuni, R.G. Chapman, R.E. Holmlin, S. Takayama, G.M. Whitesides, A survey of structure-property relationships of surfaces that resist the adsorption of protein, Langmuir 17 (2001) 5605-5620.

[44] S. Itoh, C. Susuki, T. Tsuji, Platelet activation through interaction with hemodialysis membranes induces neutrophils to produce reactive oxygen species, J. Biomed. Mater. Res. Part A 77A (2006) 294-303.

[45] F. Krötz, H.Y. Sohn, T. Gloe, S. Zahler, T. Riexinger, T.M. Schiele, B.F. Becker, K. Theisen, V. Klauss, U. Pohl, NAD(P)H oxidase-dependent platelet superoxide anion release increases platelet recruitment, Blood 100 (2002) 917-924.

[46] N. Ryszawa, A. Kawczynska, J. Pryjma, M. Czesnikiewicz-Guziki, T. AdamekGuziki, M. Naruszewicz, R. Korbut, T.J. Guziki, Effects of novel plant antioxidants on platelet superoxide production and aggregation in atherosclerosis, J. Physiol. Pharmacol. 57 (2006) 611-626.

[47] Y. Sun, L.W. Oberley, Y. Li, A simple method for clinical assay of superoxide dismutase, Clin. Chem. 34 (3) (1988) 497-500.

[48] G.D. Mao, P.D. Thomas, G.D. Lopaschuk, M.J. Poznansky, Superoxide dismutase (SOD)-catalase conjugates. Role of hydrogen peroxide and the Fenton reaction in SOD toxicity, J. Biol. Chem. 268 (1993) 416-420.

[49] S. Wen, F. Zheng, M. Shen, X. Shi, Surface modification and PEGylation of branched polyethyleneimine for improved biocompatibility, J. Appl. Polym. Sci. 128 (2013) 3807-3813.

[50] G.A. Truskey, F. Yuan, D.F. Katz, Transport Phenomena in Biological Systems, 2nd ed., Prentice Hall, New Jersey, 2010.

[51] P. Favia, R. d'Agostino, Plasma treatments and plasma deposition of polymers for biomedical applications, Surf. Coat. Technol. 98 (1998) 1102-1106. 